\title{
Control of adult neurogenesis by programmed cell death in the mammalian brain
}

Jae Ryun Ryu ${ }^{1 \dagger}$, Caroline Jeeyeon Hong ${ }^{2 \dagger}$, Joo Yeon Kim', Eun-Kyoung Kim²,3, Woong Sun ${ }^{1 *}$ and Seong-Woon $\mathrm{Yu}^{2,3^{*}}$

\begin{abstract}
The presence of neural stem cells (NSCs) and the production of new neurons in the adult brain have received great attention from scientists and the public because of implications to brain plasticity and their potential use for treating currently incurable brain diseases. Adult neurogenesis is controlled at multiple levels, including proliferation, differentiation, migration, and programmed cell death (PCD). Among these, PCD is the last and most prominent process for regulating the final number of mature neurons integrated into neural circuits. PCD can be classified into apoptosis, necrosis, and autophagic cell death and emerging evidence suggests that all three may be important modes of cell death in neural stem/progenitor cells. However, the molecular mechanisms that regulate PCD and thereby impact the intricate balance between self-renewal, proliferation, and differentiation during adult neurogenesis are not well understood. In this comprehensive review, we focus on the extent, mechanism, and biological significance of PCD for the control of adult neurogenesis in the mammalian brain. The role of intrinsic and extrinsic factors in the regulation of PCD at the molecular and systems levels is also discussed. Adult neurogenesis is a dynamic process, and the signals for differentiation, proliferation, and death of neural progenitor/ stem cells are closely interrelated. A better understanding of how adult neurogenesis is influenced by PCD will help lead to important insights relevant to brain health and diseases.
\end{abstract}

Keywords: Adult neurogenesis, Programmed cell death, Neural stem cells, Neuroblasts, Apoptosis, Autophagy, Necrosis

\section{Background}

Programmed cell death (PCD) is a type of cell death by design that mainly occurs during embryonic development. The presence of neuronal PCD during development was first discovered by Beard in the 19th century, and the extent of PCD in many different neuronal populations, the underlying molecular mechanisms, and the biological roles of PCD have been studied since the 1980's [1]. In particular, discoveries of key molecules regulating $\mathrm{PCD}$, including caspases and the $\mathrm{Bcl}-2$ family proteins, have fueled the study of developmental PCD.

\footnotetext{
* Correspondence: woongsun@korea.ac.kr; yusw@dgist.ac.kr

${ }^{\dagger}$ Equal contributors

'Department of Anatomy, College of Medicine, Korea University, Seoul 136-705, Republic of Korea

${ }^{2}$ Department of Brain and Cognitive Sciences, Daegu Gyeongbuk Institute of Science and Technology (DGIST), Daegu 711-873, Republic of Korea

Full list of author information is available at the end of the article
}

The biological importance of PCD has also been addressed using animals with mutations in genes controlling $\mathrm{PCD}$. The roles of PCD during nervous system development appear to be classified into three main categories: 1) regulation of the size of progenitor populations, 2) error correction and 3) systems matching. Each of these roles is associated with the optimization of systems by the removal of erroneous or unwanted neural populations for sculpting the nervous system during development. One of the most studied types of neuronal PCD is the targetdependent survival of peripheral neurons. For example, about $50 \%$ of sensory neurons or motor neurons innervating their targets (e.g. skin or muscle, respectively) eventually undergo PCD during their provisional synapse formation. Because supplements of additional targets or appropriate neurotrophic factors rescue them from death, it is believed that target-derived neurotrophic signals are 
responsible for the survival of innervating neurons (neurotrophic hypothesis). Competition among innervating young neurons is critical for the selection of surviving vs. dying neurons, and the limited amount of neurotrophic factors appears to determine the extent of PCD [2-7]. However, how neurotrophic factors select 'winners' and 'losers' are less understood.

More recently, the presence of neural stem cells (NSCs) and the spontaneous production of new neurons from these cells in the adult brain have been identified. Adult NSCs are cells that have the potential to selfrenew and differentiate into multiple cell types including neurons, astrocytes, and oligodendrocytes in the adult nervous system [8]. Newly generated neurons derived from adult NSCs become physiologically mature and are functionally integrated into the preexisting neural circuit [9]. They are known to be involved in several brain functions and behaviors including learning and memory [10, 11]. Adult neurogenesis is a dynamic process recapitulating the development of the embryonic nervous system and is modulated by various physiological and pathological activities at all stages: proliferation and differentiation of NSCs, migration, survival, maturation, and integration of newborn neurons.

Because adult neurogenesis is an extension of the embryonic development of the nervous system, PCD also plays an important role in the regulation of adult neurogenesis and the integration of young neurons into mature neural circuits [12]. Although the molecular machineries controlling PCD appear to be the same in the developing and adult brains, neuronal competition in particular is quite different. In the developing nervous system, competition for neuronal survival occurs among immature embryonic neurons with similar developmen$\mathrm{tal} /$ differentiation stages. On the other hand, young neurons in the adult brain likely compete with young neurons in similar stages and with preexisting mature neurons for survival and/or circuit integration. In this respect, PCD in the adult brain may have unique regulatory mechanisms or biological utility; only a few studies have addressed this issue. In this review, we focus on current knowledge of adult neurogenesis and the contribution of PCD as a regulatory strategy, and discuss potential roles of PCD in adult brain function.

\section{Neurogenesis and PCD in the adult brain}

Neurogenesis was traditionally accepted to occur during embryonic developmental in the mammalian central nervous system (CNS), but in the 1960s it was suggested by Altman and Das that new neurons from progenitor cells were continuously added throughout adulthood [13]. Since then, technical advances have allowed researchers to demonstrate adult neurogenesis. The identification of newborn neurons in the adult CNS has been made possible in large part by three different approaches: 1) analyzing the incorporation of the nucleotide analogues $\left[{ }^{3} \mathrm{H}\right]$-thymidine or bromodeoxyuridine (BrdU) during cell division, 2) genetic marking by stereotaxic injection of retrovirus carrying a reporter gene into the adult brain, and 3) tracking the expression of specific markers and the development of transgenic models under specific promoters [14]. Although these approaches have been used successfully to investigate adult neurogenesis, they each have disadvantages and limitations, leading to discrepancies among studies. Although nucleotide analogues can be used to cover the entire population of newborn neurons, their incorporation does not occur only during cell division. They can be incorporated into newly synthesized DNA resulting from the DNA repair process and even in postmitotic neurons after brain injury [15]. Furthermore, these nucleotide analogues may influence the normal process of adult neurogenesis [16]. Retroviral injection is useful for the direct visualization of newborn neurons, but it requires invasive surgical procedures and covers only a limited number of new neurons [17-21]. Non-invasive genetic labeling of adult-born cells in transgenic animal models, such as the inducible Cre recombinase and tamoxifen-regulated system (Cre-ER), is an alternative approach that is now being successfully applied [22-25]. Specific markers for NSCs and newborn neurons cover the entire population of newborn cells and can be used for human samples, but they are expressed transiently and sometimes nonspecifically in other cell types. Therefore, these approaches should be used carefully, and a combination of these methods will help avoid false interpretation of the results. Recently, a birth-dating method to measure carbon-14 $\left(\mathrm{C}^{14}\right)$, derived from nuclear bomb testing, has been applied to demonstrate adult neurogenesis in humans [26-28].

Although various techniques have been developed to easily detect the generation of new neurons in the adult brain, the assessment of PCD in the adult brain is not easy. Dead cells are efficiently removed by immune cells such as microglia in the brain $[29,30]$. In some cases, immature neuroblasts also contribute to the clearance of dead cells in the dentate gyrus [31]. Therefore, the presence of dead cells may be transient as a result of active clearance and may render the identification and quantification of dead cells in the adult brain very complicated [32]. In this respect, knockout mice that fail to execute PCD, such as Bax-knockout mice, have been efficiently used to assess the extent and distribution of PCD in the adult brain [33, 34].

Adult neurogenesis actively occurs in spatially restricted brain regions of the mammalian CNS throughout adulthood [35]. Spontaneous neurogenic regions refer to brain regions that spontaneously produce new 
neurons in adults under normal conditions. The subventricular zone (SVZ) of the lateral ventricle and the subgranular zone (SGZ) of the hippocampal DG in adults continuously and spontaneously generate neurons under normal conditions. Although adult neurogenesis in these two spontaneous neurogenic regions is well established, reports of the presence of NSCs and spontaneous adult neurogenesis in other brain regions, called nonneurogenic regions, are conflicting (Fig. 1). Neurosphere assays and the labeling of specific markers have identified the presence of NSCs in the spinal cord, cerebral cortex, cerebellum, and retina [36-39].

\section{PCD in neurogenic regions possessing active NSCs SVZ}

NSCs in the adult SVZ, located adjacent to the ependymal cell layer of lateral ventricles, proliferate and differentiate to immature neurons. Newborn neurons in this region migrate tangentially into the olfactory bulb (OB) through the rostral migratory stream to become granule neurons and periglomerular neurons [40]. The RMS is guided through chain migration via the formation of elongated cell aggregates. During migration, blood vessels are closely associated with chains of cells to form a scaffold for migration [41, 42]. At 2 weeks after birth in the adult brain, most newborn neurons have reached the $\mathrm{OB}$ and move radially toward the granule cell layer and the periglomerular cell layer in the OB. This migration is regulated by interactions between cells or between the cell and the extracellular matrix; the ephrin family of proteins, ErbB4, neural cell adhesion molecule (NCAM), and reelin are known to be involved in this process [43]. Secretory signals, such as hepatocyte growth factor (HGF), glutamate, and gamma aminobutyric acid (GABA) also contribute to the regulation of chain migration [44-46]. Newborn neurons become more complex in morphology, developing elaborate dendrites and axon. Granule neurons are morphologically mature at 2 weeks and periglomerular neurons at 4 weeks after their birth. During maturation, they form synapses, receiving synaptic inputs through dendritic spines. It has been estimated that $60,000-120,000$ cells in 2-month-old rats and 30,000 cells in adult mice are integrated into $\mathrm{OB}$ neural circuits daily [33, 47-49]. However, $50 \%$ of neural progenitor cells (NPCs) and young neurons undergo PCD to eliminate superfluous cells, and the remaining neurons can survive up to 1 year $[49,50]$. Neurogenesis in the SVZ is regulated by diverse mechanisms. Sensory input has been shown to be critical for the survival of adult-born neurons during neuronal maturation [50]. Neurotrophic factors [51, 52], growth hormones [53], and neuropeptide Y [54, 55] have been reported to play a role in adult SVZ neurogenesis. Although the function of adult SVZ neurogenesis is

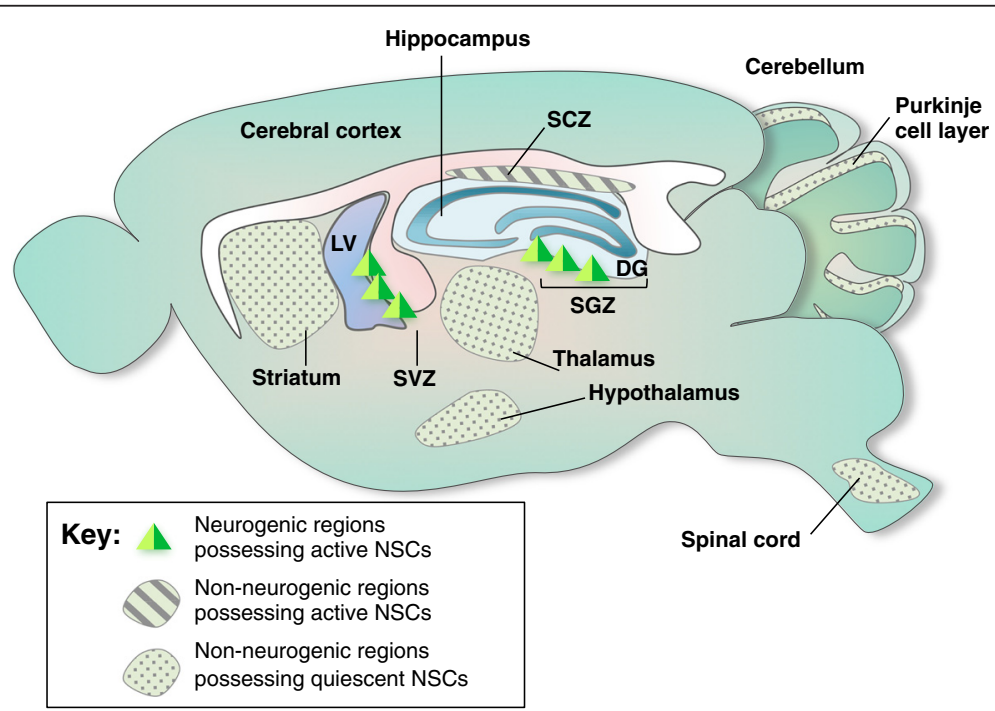

Fig. 1 Adult neurogenesis in spontaneous neurogenic regions and non-neurogenic regions. Neurogenic regions possessing active neural stem cells (NSCs): In the adult brain, neurogenesis in the subgranular zone (SGZ) of the hippocampal dentate gyrus (DG) and the subventricular zone (SVZ) of the lateral ventricle actively supplies newly generated cells. SGZ and SVZ have been identified as spontaneous neurogenic regions possessing self-renewing neural stem cells (NSCs) and neural progenitor cells (NPCs), respectively. Non-neurogenic regions possessing active NSCs: In addition to these two discrete regions, subcallosal zone (SCZ) is the sources for continuously generating multi-potent NSCs. Non-neurogenic regions possessing quiescent NSCs: Recent reports have suggested that NSCs may be widely distributed in the adult brain. The existence of NSCs is proposed by in vitro neurosphere culture and $\mathrm{BrdU}^{+}$labeling in many regions which were previously believed to be non-neurogenic, such as striatum, thalamus, hypothalamus, spinal cord, and Purkinje cell layer of the cerebellum. One of the difficulties for identifying NSCs in the nonneurogenic regions is possibly due to the mitotic quiescence of the NSCs, which has inducible capacity for self-renewal and multi-potency under pathological conditions 
unclear, it is involved in odor memory [10, 56-58] and pheromone-related social interactions [59].

It is important to note that the SVZ is poorly developed in humans, and compared with the rodent SVZ, the human SVZ has lower numbers of proliferating cells and neurons [60-62]. Arguably, the human brain lacks chains of migrating neuroblasts from the SVZ to the OB [62-64]. At this point, it remains unclear whether this structural difference requires different regulatory mechanisms in humans and rodents.

\section{$S G Z$}

In the adult SGZ, hippocampal NSCs are juxtaposed with a dense layer of granule cells in the DG. They proliferate and differentiate into immature granule neurons. Depending on the context, 30-70\% of the newborn neurons survive, but the remainder die between the first and second week after birth. Surviving neurons then migrate into the granular cell layer and send axons to form functional synapses on CA3 pyramidal neurons 2 weeks after birth, and the newly formed synapse becomes stable at 4 weeks [65]. Dendrites from the newborn neurons reach the outer molecular layer within 4 weeks [66]. During maturation, dendritic refinement and synapse formation in newborn neurons are very tightly regulated by diverse mechanisms. Silencing of Disrupted-In-Schizophrenia-1 [67], class 3 Semaphorin [21], kinesin II motor protein [68], and glucocorticoid receptors [69] in newborn granular neurons affects their dendritic growth and cell positioning. In addition, aging, electrical activity, enriched environment, and physical exercise dynamically regulate the proliferation of NSCs and the survival and differentiation of newborn neurons in the adult hippocampus [14, 70, 71]. Approximately $30-70 \%$ of newly generated neuroblasts are eliminated within the first month after birth during their integration period, depending on the animals' physiological/pathological condition and their experience [72]. We have estimated how many neurons undergo PCD by analyzing the number of newborn neurons in Bax-knockout mice in which PCD is completely blocked [73]. The number of DG cells in Bax-knockout mice increased 2-fold by 12 months compared to WT mice, whereas DG cell numbers were similar at 2 months. These data suggest that PCD is marginal during the early postnatal period when the DG is forming, but PCD is an important factor for regulating adult neurogenesis. It appears that 1,300 cells undergo PCD daily and are replaced by newborn neurons in the adult mouse DG. Comparably, in humans, 700 new neurons, or $0.004 \%$ of DG neurons, are added in each hippocampus per day [74]. This means that $1.75 \%$ of the neurons within renewing populations are annually renewed in the human brain during adulthood.
These results indicate that PCD also plays a significant role in the regulation of adult neurogenesis in humans.

\section{PCD in non-neurogenic regions possessing active NSCs $S C Z$}

Recently, the subcallosal zone (SCZ) has been identified as a neuroblastogenic region in the adult brain [75]. The SCZ is located beneath the neocortex and is closely associated with white matter. Most cells born in adult SCZ migrate into the corpus callosum and become oligodendrocytes [37]. Compared with the SVZ and SGZ, newborn neurons in the SCZ undergo virtually complete PCD regulated by Bax. Newborn neurons survive in Bax-knockout adult mice but not in wild-type mice; however, they fail to become functionally mature neurons due mostly to the absence of appropriate neurotrophic supports [38, 75]. A functional role for neurogenesis in the adult SCZ is indicated by the fact that focal traumatic brain injury promotes neurogenesis in this region, which suggests that the adult SCZ maintains neurogenic potential that could contribute to recovery in the injured brain. Although the biological utility of neuroblastogenesis in the $\mathrm{SCZ}$ is yet unclear, this observation suggests that PCD is one of main strategies involved in determining the content of neurons integrating into mature neural circuits. Similarly, dividing Pax6- and Olig2-positive NSCs within the subcortical white matter continually produce doublecortin (DCX)-positive new neurons, but they are lost within a week of their birth [38].

The SCZ, which, in the human brain, is often called subcortical white matter, is well-developed in humans, and the embryonic SCZ contains transient neurons that might be postnatally eliminated by PCD [76]. Previously, Roy et al. found that the human SCZ possess mitotically competent progenitor cells, most of which differentiate into oligodendrocytes in vitro; however, a very small fraction of these cells are found to mature into neurons [77]. These observations indicate that these progenitors have the potential for multilineage differentiation. Later, this group of researchers confirmed that human whitematter progenitor cells from the SCZ can produce functionally mature neurons and glia in vitro and after xenograft to the fetal rat brain [78]. However, further studies are needed to understand the regulatory mechanism of adult neurogenesis in the human SCZ, including PCD.

\section{PCD in non-neurogenic regions possessing quiescent NSCs}

The isolation of proliferating cells from many nonneurogenic regions in the adult brain and their differentiation into neurons in vitro and in vivo after transplantation has led to the emerging view that NSCs may be widely distributed in the adult brain, although there are still discrepancies among studies. Whether neurogenesis occurs in the adult neocortex is heavily debated. Several 
reports have shown that the neocortex generates neurons in the adult rat [79], hamster [80], and macaque $[81,82]$, whereas others have shown that there are no adult-born neurons in the neocortex [27, 83, 84]. Which regions of the brain produce newborn neurons in the neocortex are also matters of debate. It has been shown that new neurons are added to the neocortical association areas in the adult macaque, but it appears that they migrate from the SVZ through the white matter [81]. The fact that NG2-immunoreactive neurons were found in the neocortex indicates newborn neurons originate from the cortex itself, as neural/glial antigen 2 (NG2)positive precursors reside within this area [79]. In fact, many recent studies have reported that new neurons are generated in the adult mammalian neocortex under pathological conditions $[46,85,86]$. These reports suggest the presence of NSCs in the neocortex, which can be upregulated by brain injury.

Contradictory results, however, have been shown in other brain regions including the striatum, amygdala, substantia nigra, brainstem, olfactory tubercle, and piriform cortex [87]. The neurogenic potential of the adult spinal cord was identified by characterizing neurosphereforming cells isolated from the adult spinal cord [64, 88]. The number of putative NSCs from the adult spinal cord is greatly increased by spinal cord injuries [89, 90]. The nature of these neurosphere-forming cells in terms of whether they possess ependymal or glial characteristics is still under debate [91-94].

Growing evidence suggests that the adult cerebellum contains cells with characteristics of NSCs. Bergmann glia, radial glia present in the Purkinje cell layer, express the neural stem markers Sox1/2/9 in the adult cerebellum $[74,95]$. Purified NSCs from the postnatal murine cerebellum can form self-renewing neurospheres and differentiate into multiple cell types including neurons in vitro and in vivo after transplantation [96]. Upon transplantation to the perinatal cerebellum, NSCs from the cerebellum differentiate into region-specific cerebellar neurons and acquire the mature electrophysiological properties of cerebellar granule cells [97].

A small group of retinal stem cells persists at the margin of the retina in most vertebrates. Retinal stem cells in fish and amphibians continue to produce progenitors throughout life, adding new retina to the periphery of the existing retina. This new retinal addition is limited in birds and not evident in mammals. Putative NSCs from the retinal periphery and ciliary body of mammals can be isolated and grown in vitro for extended periods [36]. A variety of cell types have been suggested to potentially act as neural progenitors in the adult mammalian retina, including Müller glia [98], ciliary epithelium [64], and iris pigment epithelial cells [76]. The neurogenic potential of Müller cells was initially identified in lower vertebrates [63, 99] and later in humans [100]. Ciliary epithelial stem cells are present in a mitotically quiescent state in the adult mammalian eye and under in vitro conditions, they begin to express sodium and potassium channels and thereby develop into functional neurons [64]. They also respond to specific cues in culture conditions and preferentially differentiate along the lineages of retinal ganglion cells (RGCs) and rod photoreceptors [101]. Similar to other retina stem cells, pure isolated iris pigment epithelial cells express neural progenitor markers and differentiate into neurons and glial cells [76].

Adult neurogenesis in the hypothalamus has also been reported [102, 103]. Hypothalamic radial glialike ependymal cells (tanycytes) from the median eminence generate newborn neurons in the adult hypothalamus [104]. Neurogenesis in the adult hypothalamus is involved in determining the weight and metabolic activity of adult mice [102]. Furthermore, postnatal hypothalamic neurogenesis is regulated by a high-fat diet [105]. In addition to the hypothalamus, the striatum, septum, and thalamus maintain NSCs that are activated upon exposure to certain growth factors and regulatory signals in situ [102, 106]. Additional studies have also reported on the production of new neurons in the rat midbrain [107], although this remains controversial $[108,109]$.

Notably, an in vitro neurosphere assay has been used to demonstrate the presence of NSCs in many non-neurogenic regions by assessing the potential of distinct populations to form neurospheres in vitro. However, a recent publication by Codega et al. challenges the utility of this assay to identify 'quiescent' stem cells in vivo. Quiescent NSCs, which rarely form neurospheres or adherent colonies in vitro, might be present in distinct brain regions in vivo. Only activated NSCs, which actively divide in vivo, can form neurospheres in vitro [110]. This suggests that there might be additional non-neurogenic regions that possess potential NSCs, possibly quiescent NSCs, which are not actively dividing and neurosphere-forming NSCs.

In summary, accumulating evidence has shown that adult NSCs are present in many brain regions other than the spontaneously neurogenic SVZ and SGZ, although they cannot be easily identified because of their mitotic quiescence, slow dividing activity, or potentially massive PCD under normal conditions (Fig. 1). Therefore, it becomes more important to explore the mechanism by which nonneurogenic brain regions regulate the proliferation of NSCs and their differentiation into neurons in normal and pathological conditions in order to better understand adult neurogenesis. 


\section{Principles and key molecules of PCD}

The molecular process and causality of PCD in the CNS have been central topics of continuous research in the past decades. We briefly highlight core regulatory molecules and biochemical pathways of apoptosis, autophagy, and necrosis in this section, followed by a review of new insights into PCD for the control of adult neurogenesis in the next section (Fig. 2).

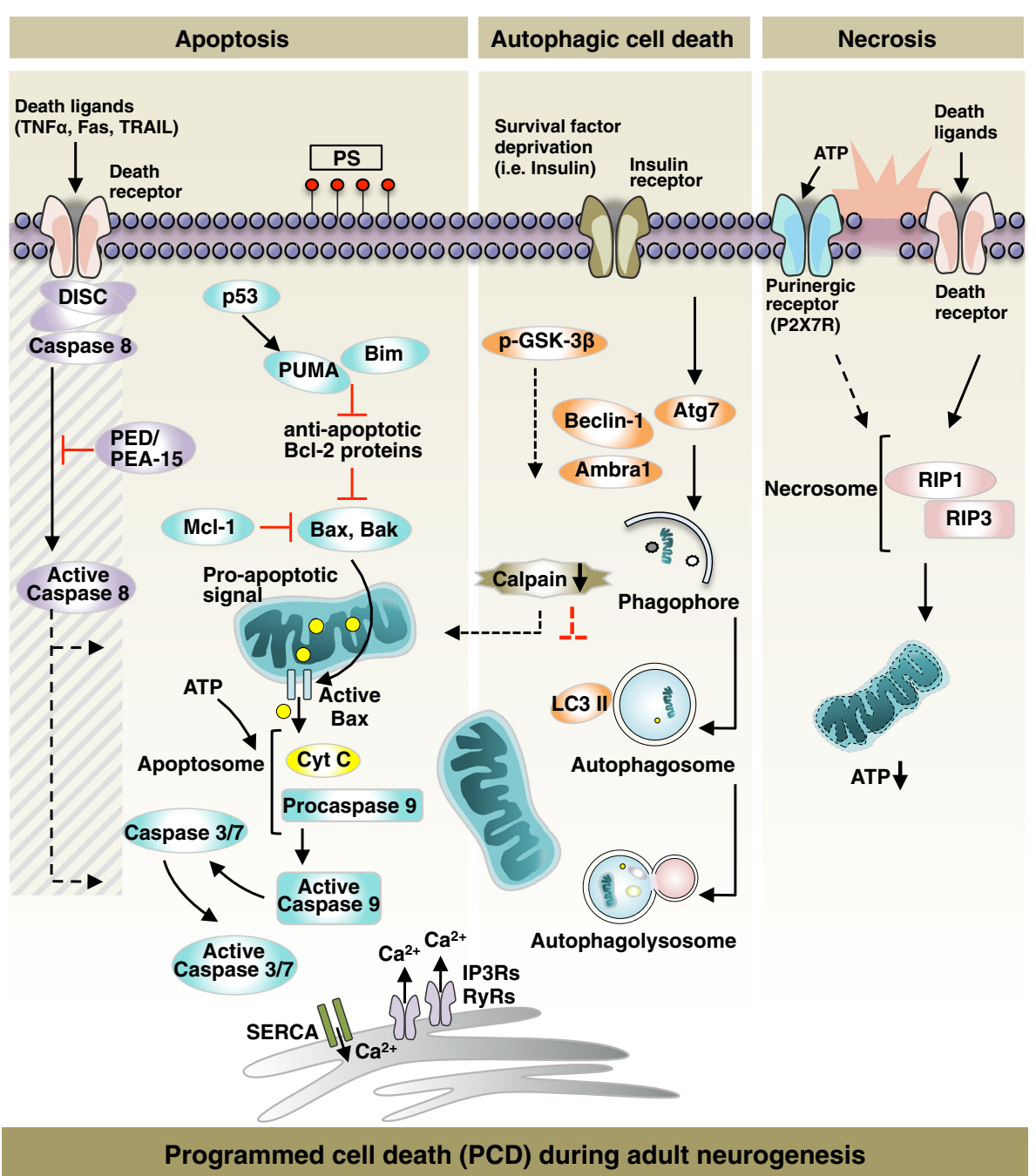

Fig. 2 The key players in the regulation of PCD during adult neurogenesis. Apoptosis: Pro-apoptotic signals induce Bax translocation to the outer membrane of mitochondria. Bax-mediated pore formation leads to the release of apoptogenic cytochrome c (Cyt c) into the cytosol and apoptosome formation. The apoptosome activates procaspase- 9 and catalytically active caspase-9 induces activation of downstream effector caspases, caspase-3 and -7 (Caspase 3/7). Phosphatidylserine (PS) exposure at the cell surface is required for the clearance of apoptotic cells. In the adult neural stem cells (NSCs), p53, Bim and PUMA have been implicated in activating apoptosis. In addition, the pro-apoptotic proteins, Bax and Bak are the key regulators. Mcl-1 antagonizes the pro-apoptotic proteins, and therefore, considered as a critical anti-apoptotic protein for the survival of the NSCs. In extrinsic apoptosis, a death ligand (TNFa, Fas, or TRAIL) binding activates death receptor and induces DISC complex formation near the receptor. Upon DISC complex-mediated activation of caspase-8, intrinsic and extrinsic apoptosis converge at the level of the executioner caspase cascade. In adult NSCs, PED/PEA-15 represses the activation of caspase-8. Release of $\mathrm{Ca}^{2+}$ from the ER and subsequent transfer to the mitochondria promtes the commitment of NSCs to cell death. Autophagic cell death (ACD): Autophagy is induced when cells are starved of nutrients or survival factors. Atg7 regulates the maturation of autophagosome and initiates the lipidation of LC3 (also called LC3 II). Cargos subjected to degradation are degraded in the autophagolysosome. AMBRA1 and Beclin-1-induced autophagy is inversely correlated with apoptosis in adult NSCs. Under insulin-deprived condition, the adult hippocampal neural stem (HCN) cells succumb to ACD wherein the cell fate

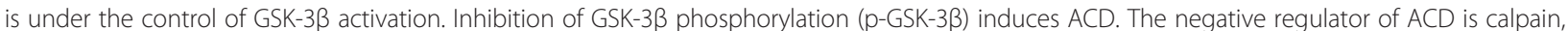
which also mediates the crosstalk between apoptosis and ACD. Necrosis: Extracellular ATP or death receptor activation rapidly induces RIP1/RIP3 necrosome formation. Necrotic cell death results from the depletion of cytoplasmic ATP due to mitochondrial dysfunction. A purinergic P2X7 receptor-mediated necrosis induction has been reported in adult NSCs. However, regulator of necrosis in adult NSCs has not been identified to date 


\section{Apoptosis}

Cells undergoing apoptosis can be morphologically distinguished by the progressive appearances of the following features: 1) cytoplasmic condensation, 2) nuclear shrinkage (pyknosis), 3) nuclear fragmentation (karyorrhexis), and 4) non-immunogenic engulfment by nearby macrophages (phagocytosis) [111, 112].

Apoptosis is categorized into two types: intrinsic and extrinsic. In the mitochondrial pathway of intrinsic apoptosis, Bax and Bak activation causes: 1) permeabilization of the mitochondrial outer membrane, 2) the release of mitochondrial apoptogenic proteins including cytochrome c to the cytosol through protein permeable-pores and 3) the execution pathway involving the activation of caspases (mainly caspase-3, caspase-6, and caspase-7) [113-115]. Lastly, apoptotic cells expressing phosphatidylserine at the external surface are eliminated by phagocytic cells [116]. Overexpression of the pro-survival $\mathrm{Bcl}-2$ family proteins, i.e., $\mathrm{Bcl}-\mathrm{X}_{\mathrm{L}}$, prevents $\mathrm{Bax}$ oligomerization in the outer membrane of the mitochondria, protecting cells from commitment to the apoptotic pathway $[117,118]$. Several death effectors, including DNA damage, induce caspaseindependent apoptosis via the translocation of AIF1 from mitochondria to the nucleus [119].

Extrinsic apoptosis is initiated by ligand-mediated activation of death receptors, including those for tumor necrosis factor (TNF), Fas, TNF-related apoptosis-inducing ligand (TRAIL), etc. [120]. Ligand binding stimulates the assembly of the death-inducing signaling complex (DISC) - which includes FADD and pro-caspase-8-near the receptor [120]. After caspase- 8 activation, the extrinsic apoptosis pathway converges with the intrinsic apoptosis pathway at the level of executioner caspases [116].

\section{Autophagy}

Autophagy (from Greek, meaning 'self-eating') is a catabolic pathway by which bulk cytoplasmic materials-including macromolecules and organelles-are degraded in a selective or a non-selective manner [121]. Cells undergoing autophagy display autophagic vacuolar structures including autophagosomes and autolysosomes, the products of autophagosome fusion with lysosomes [122]. The process of synthesis of autophagosome, the engulfment of autophagy substrates, the autophagolysosomal maturation, and the degradation of materials by lysosomal hydrolases is denoted as 'autophagy flux' [123]. Through its role in recycling proteins and catalyzing dysfunctional cytoplasmic organelles, autophagy is undoubtedly involved in a variety of physiological cellular processes including cell survival and death, metabolism, development, and aging.

Besides its role in maintaining cellular homeostasis, autophagy is a direct contributor to cell death in a variety of species including yeast, Drosophila, and mammalian cells [124]. Although apoptosis, autophagy, and necrosis have distinct signaling pathways, many biochemical components converge. Therefore, apparent changes in the expression of autophagy-related molecules are insufficient to implicate autophagy as a direct contributor of cell death. Based on accumulating evidence for the role of autophagy in PCD, recent studies have established discernible criteria for autophagic cell death (ACD): 1) cell death does not accompany the activation of apoptosis executers; 2) dying cells have increased autophagic flux; and 3) autophagy suppression rescues or prevents cell death $[125,126]$.

\section{Necrosis}

The death ligands that drive cells to apoptosis can kill cells via necrosis as well [127]. Although necrosis is one of the three modalities of PCD, necrosis-specific molecular processes leading to cell death in a programmed manner are relatively unknown. Receptor-interacting protein (RIP) kinases are core regulators of necrotic cell death [128]. Knockdown or chemical inhibition of RIP1 by necrostatin1 inhibits TNF-induced necrotic cell death [128].

The intracellular concentration of ATP provided either by glycolysis or mitochondrial respiration is a determinant of the molecular switch between apoptosis and necrosis; prolonged depletion of intracellular ATP levels shifts cells to undergo necrotic cell death $[129,130]$.

\section{PCD for the control of adult neurogenesis}

Aiming to understand factors that control the balance between NSC proliferation and death during neurogenesis in the adult brain, this section will attempt to bring together existing in vivo evidence supporting the idea that adult neurogenesis is regulated by PCD with in vitro molecular studies to gain insight into the molecular and cellular mechanisms of PCD during adult neurogenesis. It is very challenging to directly demonstrate the molecular mechanisms of cell death of NSCs in vivo; therefore, it is imperative to extrapolate the relevant mechanisms and potential roles of cell death regulators in neurogenesis from in vitro biochemical studies [131]. Therefore, we will mostly consider studies of NSC death in in vitro NSC cultures in order to identify mechanisms that could provide insight into adult neurogenesis in vivo, because our particular interest is in understanding the molecular mechanisms of PCD and how it affects neurogenesis in the adult brain.

\section{Apoptosis of NSCs}

\section{Intrinsic apoptosis in the adult NSCs}

The survival of NSCs is dependent on growth factors in neurogenic niches. FGF-2, a mitogen, is one of the factors that regulate proliferation and postmitotic cell fate [132]. When deprived of growth factors, NSCs undergo apoptosis. Adult NSCs possess multiple checkpoints along the PCD signaling pathway to repress or promote 
cell death. For example, NSCs from $b a x^{-1-} b a k^{-/-}$mice are resistant to growth factor deprivation-induced apoptotic cell death. Also, adult NPCs in the SVZ are more susceptible to apoptosis when Mcl-1 is conditionally knocked out, whereas Mcl-1 overexpression reduces endogenous apoptosis by $50 \%$ in nestin-positive adult NPCs from the SVZ [133]. These reports indicate that mitochondrial apoptotic pathway is essential PCD in newly generated cells in the neurogenic regions [73] and Bcl-2 family proteins function as regulators of NSCs commitment to mitochondria-dependent apoptosis. As such, bax-deficient NSCs are viable when subjected to apoptosis-inducing stimuli such as staurosporine, a prototypical inducer of apoptosis which inhibits multiple kinases, or etoposide [134]. On the other hand, adult wild-type NSCs show characteristic mitochondrial apoptotic markers, including the release of cytochrome c, cleaved caspase-3, and DNA fragmentation when stimulated with staurosporine [135]. Although mitochondriadependent apoptotic pathways seem to be critical in the death of NSCs derived from different neurogenic regions, further comparative studies are required to understand regional differences in the molecular signaling mechanisms and reveal a unified or region-specific mechanism of the intrinsic apoptosis in the adult NSCs.

In the DG, Bim or PUMA deficiencies also lead to significant enhancement of the survival of newly developed neurons [136]. PUMA is a downstream target gene of p53, which is a transcriptional regulator of apoptosis upon cellular stress [137]. p53-dependent apoptosis in NSCs of DG and OB is mediated by PUMA $[137,138]$. In addition, p53 deficiency enhances proliferation and induces differentiation toward neuronal and glial cell types in SVZ [139]. However, in contrast to these reports on the inhibition of NSC self-renewal by p53, there are reports on the surprising increase of cell death in the neurogenic regions of mice deleted of p53 [140, 141]. Therefore, the exact role of p53 in regulation of NSCs remains unsettled.

Recently, a number of studies have shown that endoplasmic reticulum (ER)- mitochondrial $\mathrm{Ca}^{2+}$ promotes the commitment of NSCs to cell death. The close proximity of the ER and mitochondria permits synergistic intracellular signaling events, including lipid biosynthesis, $\mathrm{Ca}^{2+}$ transmission, and mitochondrial fusion and fission dynamics [142]. $\mathrm{Ca}^{2+}$ transfer at the ER-mitochondria contact site mediates the initiation of apoptosis. VDAC1, Akt, Bax, Bak, and Bcl-2 modulate the discharge of intracellular $\mathrm{Ca}^{2+}$ from the ER to mitochondria via the SR $\mathrm{Ca}^{2+}$ ATPase and the inositol 1,4,5-trisphosphate (IP3) receptor [143-146]. NSCs/NPCs are sensitive to regional changes in $\mathrm{Ca}^{2+}$ concentration. Bax-knockout SVZ NSCs are less prone to caspase-3 mediated cell death. Moreover, Bax is a major determinant of apoptosis in adult NSCs, and its action is mediated by the modification of IP3 receptormediated calcium flux [147]. Knockdown of either Bax or IP3 receptor significantly improved cell survival, thereby strengthening the role of ER in the PCD of NSCs/NPCs. In the adult neurogenic SVZ and SGZ, apoptotic NSCs are phagocytosed by unchallenged microglia [32].

\section{The extrinsic apoptotic signaling pathway is non-functional in adult NSCs}

Upon ischemic injury in the adult brain, neurons undergo extensive apoptotic cell death mediated by death receptor ligands, including TRAIL, Fas, and TNF- $\alpha$ [148]. Whether NSCs undergo apoptosis via the death receptor-mediated extrinsic apoptotic pathway in response to pro-inflammatory cytokines released by activated microglia is of great interest. In murine NSCs, activation of the Fas receptor by Fas ligand (FasL) does not induce apoptosis, suggesting that NPCs are insensitive to death receptormediated apoptosis despite the fact that the Fas receptor is endogenously expressed [149]. FasL treatment increased phosphorylation of ERK in a caspase-8 independent manner, which suggests that FasL promotes growth rather than death in NSCs $[149,150]$. Similar to the effect of FasL on adult NSCs, TNF activation does not cause extensive apoptotic death in adult NSCs. In vitro TNF- $\alpha$ treatment for up to three days induced a low level of DNA fragmentation in adult SVZ NSCs, suggesting that adult NSCs have high thresholds for the induction of TNF- $\alpha$ induced activation of the extrinsic apoptotic pathway [151]. Sox-2 positive adult NSCs express TLR2 and TLR4, and when these cells are challenged with the TLR agonists, TNF- $\alpha$ has been found to be released from NSCs; however, this ligand did not promote either death receptor-engaged extrinsic apoptosis or the proliferation of adult NSCs [152].

The mechanism of protection against death-inducing ligands in adult NSCs has not been well characterized. In NSCs, FLIP, a well-established endogenous inhibitor of caspase-8, was found not to be responsible for the non-functional death receptor pathway [149, 150]. Instead, low expression of caspase- 8 and the competitive binding of PED/PEA-15 to FADD altogether prevent caspase-8 processing in adult NSCs [153]. The resistance to death ligands is probably an intrinsic mechanism to conserve a pool of NSCs when cytokines are overproduced following/during CNS injury.

\section{Apoptosis of migrating neuroblasts}

Elimination of erroneous or developmentally transient cell populations for error correction is one of the major functions of PCD during embryonic or early postnatal development. For example, a subset of erroneously migrating Purkinje cells are eliminated from their ectopic position in the cerebellum, a process which can be blocked by eliminating the Bax gene [154], suggesting 
that the elimination of cells that fail to migrate may be a common function of PCD to allow for error correction in the postnatal brain. Failure in neuroblast migration also appears to induce PCD in the adult brain. We observed that Bax-knockout mice exhibit a massive accumulation of ectopic neurons in the RMS where young neuroblasts are actively migrating [33]. Considering that dying cells are frequently observed in the migratory stream [155], it appears that some neuroblasts undergo PCD during their migration. In Bax-knockout mice-and due to the increased flow of neuroblasts through the relatively constant migratory tube generated by ensheathing astrocytes-glial cells were eventually displaced and the neuroblasts were released from the migratory tract. Interestingly, migrating neuroblasts express the N-Methyl-Daspartic acid receptors (NMDARs) long before synaptic integration, and a single cell-level gene knockout of the NMDARs in neuroblasts resulted in PCD [156]. Considering that vesicular release of glutamate from the ensheathing astrocytes is a major source of NMDARs activation, loss of NMDA activation might contribute to the PCD of displaced neuroblasts. However, it should also be noted that migration-defective neuroblasts do not always undergo PCD, and a subset of cells appears to be differentiated into mature neurons [157]. Currently the impact of these ectopically survived neurons are unclear, but PCD of migrating neuroblasts may serve to prevent potential errors in neural "wiring."

More recently, it was discovered that a subset of early neuroblasts (2-4 days after generation from transitamplifying cells) in the DG also undergoes PCD [1]. Considering that neuroblasts at these periods in the SGZ begin to migrate toward the interior of the granular zone, it appears that PCD-as occurs during the neuroblast stage-is common in adult neurogenic regions. However, it is unclear whether PCD during this early phase of the neuroblast population is relevant to the elimination of erroneously migrating cell populations.

\section{Apoptosis of immature neurons during neuronal integration}

It appears that the most extensive PCD occurs during the synaptogenesis of postmitotic neurons. In the normal adult brain, a considerable number of dying cells is readily observed using a variety of methods [155]. Most of these dying cells in the neurogenic regions are neuroblasts, and they can easily be identified by the expression of markers for immature neuroblasts, including DCX and PSA-NCAM. Lineage-tracing and birth-dating experiments also consistently suggest a $30-70 \%$ loss of immature neurons during the formation of provisional synaptic contacts and subsequent synaptogenesis. For example, double labeling with apoptotic and neuronal markers has shown that PCD occurs during the maturation of newly generated neurons in the DG [158160]. In addition, massive PCD is seen in the $\mathrm{OB}$ where young neuroblasts stop migrating and begin to differentiate $[47,50,161]$. PCD during the synaptogenic period is critical for the efficient establishment of synaptic connections. The mechanism that determines the survival of an optimal number of neurons during development is explained by the 'neurotrophic hypothesis' $[5,162]$. The neurotrophic hypothesis assumes that the availability of neurotrophic signals released from target organs/neurons for the survival of neurons is limited. Under this condition, competition among the neurons for access to these trophic signals eventually determines how many cells are to remain. Identification of target-derived neurotrophic factors and microsurgery or gene perturbation experiments have consistently supported the neurotrophic hypothesis as a promising model for explaining developmental PCD. It seems likely that the mechanism of PCD in adult neurogenesis is also related to the neurotrophic hypothesis. For example, there is substantial evidence correlating conditions that increase neurotrophic signals, such as physical exercise or hippocampal learning, with reduced PCD of adult-produced neurons [86, 163-165]. By contrast, conditions that suppress the expression of neurotrophic signals, such as stresses or social isolation, enhance PCD. In this respect, at least, neurotrophic factors are involved in the survival of adult-produced neurons. Although it remains unclear what and how significant a competition for neurotrophic signals plays in the selection of surviving neurons, there is evidence demonstrating the presence of competition among newly produced neurons for survival. For example, the genetic elimination of the NMDARs in a subset of newly produced neurons using a single-cell knockout technique resulted in the reduced survival of the affected neurons, whereas total number of surviving neurons remained constant by increased survival of neighboring, unaffected normal neurons [166]. This result fits neurotrophic hypothesis since, losers (affected cells) will die more than winners (unaffected cells) under the selection pressure of limited amount of glutamate receptor activation or subsequent neurotrophic signals.

Competition for survival among immature neurons essentially occurs between homogeneously immature neurons, but immature neurons in the adult brain must also compete with pre-established mature neurons for new synaptic connections. Morphological tracing has shown that newly born neurons form synapses with mature neurons [50,167-169], and they begin to receive inputs from afferent fibers by 2 weeks after birth [66, 170-172]. Considering that immature neurons efficiently incorporate into the neuronal circuit, they should be able to replace old connections. To accomplish such a replacement, either young neurons should have the 
ability to actively remove preexisting partners to form new connections, or old neurons should be spontaneously removed and provide room for young neurons. We have addressed this and related issues experimentally by blocking PCD in Bax-knockout mice. In Baxknockout mice, PCD of DG neurons is completely blocked [73]. Accordingly, the number of DG neurons progressively increases with age in Bax-KO mice. In this situation, the outnumbered adult-produced, surviving neurons form synaptic connections with efferent and afferent neurons [34]. Considering that massive loss of young neurons is prevented by Bax deletion, and that surviving neurons successfully find their synaptic partners-which are relatively constant in number-the above observation suggests that young neurons can form synapses with actively eliminated preexisting neurons. In support of this, we have found that Bax-knockout mice showed relatively normal neural circuits formed by young neurons, but mature neuronal circuits were severely impaired, indicating that long-surviving adultgenerated neurons can intercalate with mature neural circuits. In this respect, it appears that PCD of adult neurons is a means to maintain the integrity of neuronal circuits, and the failure of this process cannot be compensated by other biological events such as synaptic pruning, which occurs during embryonic development [173].

However, recent data have shown that conditional knockout of the Bax gene in the adult brain results in enhancement of pattern separation without affecting other major hippocampal functions [174]. This observation is somewhat contradictory to the neurotrophic hypothesis, because it implies that the prevention of immature neuronal death during the competitive period can enhance circuit efficacy. It is important to consider that the DG is involved in many different hippocampal functions in addition to pattern separation. In fact, it has been proposed that DG circuits mediated by immature neurons and mature neurons may have distinct functions. For instance, young neurons exhibit strong synaptic plasticity $[172,175]$ due to the lack of GABAergic inhibition [166, 175-177]. With this and other distinct cellular characteristics, immature DG neurons appear to mediate efficient pattern separation, whereas mature neurons mediate other functions such as sensory alignment [178]. Therefore, the enhancement of pattern separation following the prevention of PCD may be a transient event caused by an imbalance of immature vs. mature neuronal circuits. In fact, we also found that olfactory learning ability is improved in Bax-knockout mice while major olfactory sensation is virtually normal $[33,56]$. Collectively, the functional impact of PCD in adult neurogenesis should be evaluated by examining the interplay between young neurons and mature neurons.

\section{Apoptosis of mature neurons already integrated in the neuronal circuits}

Although the majority of neurons undergoing PCD in the adult brain are adult-generated immature neurons, mature neurons in adult neurogenic regions appear to undergo spontaneous PCD, which can cause the 'renewal' of old circuits by replacing dying mature neurons with newly produced ones. Birthdate tracing revealed that about $25 \%$ of the DG neurons generated during a major developmental neurogenic period (postnatal day 6) in rats undergo PCD during the first 1-6 months after birth [72]. Adult-born neurons that survive beyond the PCD period appear to live at least 19-21 months in both rats and mice $[49,179]$. On the other hand, newly produced $\mathrm{OB}$ neurons undergo $\mathrm{PCD}$ during the first 619 months after birth [50]. Less is known about the PCD of mature DG neurons in mice, but the total number of DG neurons is invariable in adulthood, indicating that PCD occurs in mature neurons in order to numerically match the adult-produced new neurons [73]. In this way, newly generated neurons appear to replace earlier born, older cells.

Although it is puzzling why new neurons should replace old neurons in limited spontaneous neurogenic regions, the presence of spontaneous cell replacement indicates that new neurons replacing damaged neurons in the diseased or damaged brain is possible.

\section{Autophagic cell death in adult neurogenesis}

The majority of studies on PCD during adult neurogenesis to date are limited to apoptosis. Whether other types of PCD are operating during adult neurogenesis remains largely understudied. As the first report on nonapoptotic mode of PCD in adult NSCs, we reported that adult hippocampal neural stem $(\mathrm{HCN})$ cells deprived of insulin committed to ACD despite an intact apoptosis pathway. Genetic suppression of Atg7, a component of the autophagy machinery, attenuated cell death, whereas treatment of the cells with Z-VAD-fmk, an apoptosis inhibitor, failed to attenuate cell death in such conditions [135]. Furthermore, the expression of autophagy marker proteins such as Beclin-1 and LC3 II were elevated; in stark contrast, Bcl-2 family proteins $\mathrm{Bcl}-2$ and $\mathrm{Bcl}-\mathrm{X}_{\mathrm{L}}$ were down regulated [135]. To date, the underlying molecular mechanism of ACD has not been fully understood. Recently, we have reported that activation of GSK-3 $\beta$, a well-known inducer of neuronal apoptosis, induced ACD instead of apoptosis following insulin deprivation [180]. Calpain is a cytosolic calcium-activated cysteine protease [181]. Calpain inactivation promoted ACD in insulin-deprived $\mathrm{HCN}$ cells, whereas calpain activation completely switched ACD to apoptosis, demonstrating that calpain mediates crosstalk between ACD and apoptosis in HCN cells [182]. Recently, the role of Beclin- 
1 and Ambra1-mediated autophagy has been also reported in adult neurogenesis at SVZ [183]. In adult neurogenesis, the mode of PCD in NSCs/NPCs may vary depending on the nurturing environment of the niche.

\section{Necrosis in adult neurogenesis}

Necrotic death occurs rather rarely during physiological postnatal development in the brain. Under pathological conditions such as ischemic injury and inflammation, extracellular ATP released from nearby damaged cells or glial cells evokes necrotic death in recipient cells with purinergic receptors [184]. Generally, extracellular ATP triggers the apoptotic cascade in cells as an immediate consequence of the rapid rise in cytoplasmic $\mathrm{Ca}^{2+}$. However, at a higher degree of ATP insult, cells undergo necrosis instead of apoptosis [185].

Purinergic receptors exist in not only immune cells but also non-immune cells in the CNS. Adult NPCs also express the functional purinergic $\mathrm{P} 2 \mathrm{X} 7$ receptor (P2X7R); therefore, stimulating receptor activation with extracellular ATP leads to necrotic death [186-188]. Furthermore, the purinergic receptor also mediates necrotic death in postmitotic cells. In dopaminergic neurons, extracellular ATP induced cell swelling and loss of integrity of the ER and plasma membrane-morphological hallmarks of necrotic death; these effects were blocked by treatment with a P2X7R antagonist [186].

Taken together, our understanding of the molecular mechanisms involved in necrotic death of adult NSCs/ NPCs is limited due to a lack of evidence for necrosis during adult neurogenesis. Yet, the susceptibility of NSCs/NPCs to necrotic death under pathological conditions raises the possibility that adult neurogenesis may be perturbed through necrotic mode of PCD under certain conditions.

\section{Cellular regulation of PCD in adult neurogenesis}

The stem cell pool is dynamically regulated by changes in the niche by extracellular molecules that are released from vascular endothelial cells, astrocytes, mature neurons, and peripheral sources [156, 189-194]. Humoral factors, neurotrophins, neurotransmitters, morphogens, and steroid hormones regulate the basal level of proliferation of NSCs and promote physiological survival of NSCs and newly produced neurons (Table 1). The regulatory roles of the factors in terms of survival of newly generated cells during adult neurogenesis is wellestablished in vivo studies; however, because the measures taken to date are limited to rate of volume growth, total numbers of TUNEL activity in BrdU-positive cells, caspase-3 activation, proliferation capacity, and differentiation potentials, the precise molecular mechanisms involved in PCD is not elucidated. Here, we review key regulators of neurogenic niche that have potential to control the intricate balance between survival and PCD in adult neurogenesis.

Brain IGF-1 signaling is a major regulator of brain homeostasis, and accumulating evidence suggests that IGF-1 regulates adult neurogenesis via modulation of the number of newly generated neurons and synaptogenic outputs [53, 195-198]. Homozygous or heterozygous knock out of IGF-1 receptor results in increased number of apoptotic NSCs and retarded growth of several regions of the brain including the hippocampus, cerebral cortex, and cerebellum, respectively [199]. Neurotrophins, such as nerve growth factors (NGFs), brainderived neurotropic factor (BDNF), and neurotrophin-3 (NT-3), are essential pleiotropic factors with survival and growth-promoting effects on selective neurons during embryonic development [200-203]. BDNF and NGF play a similar role as a pro-survival factor in the adult brain. It has been reported that continuous infusion of NGF for 6 days enhanced the survival of newborn DG neurons [204] and the reduced expression of BDNF or NT-3 (or their receptors) in mutant mice significantly reduced the survival of immature DG neurons [205]. Mechanistically, BDNF and NGF-mediated survivalpromoting effect is directly mediated by their antiapoptotic capacity; STS-induced PARP cleavage and caspase activation were suppressed by BDNF and NGF treatment to NSCs and the anti-apoptotic effect was mediated by activation of PI3K/Akt and MAPK pathway [206]. The multiple downstream events mediating the survival-promoting effects of neurotrophin on adult neurogenesis have begun to be elucidated [207].

Neurogenesis-related PCD are also controlled by various neurotransmitters. This is in sharp contrast to $\mathrm{PCD}$ occurring during development. In embryonic development, when significant levels of PCD are known to occur, the nervous system is still immature, and the influence of neurotransmitters is only marginal. Therefore, PCD during embryonic development is mainly controlled by neurotrophic signals, whereas neurotransmissions play important roles in the pruning of connections later. On the other hand, in the adult brain, NSCs and immature newborn neurons are all under the strong influence of mature neuronal circuits, and it appears that synaptic activity and neurotransmitters, either directly or indirectly, modulate the different stages of adult neurogenesis including PCD. Glutamate promotes survival by acting through NMDARs and metabotropic receptors (mGluRs) [208-210]. Genetic suppression of functional NMDARs have been shown to activate apoptosis in new neurons in the adult DG and $\mathrm{OB}$, therefore suggesting that NMDARs activation-mediated control of the rate of cell death is maintained in the adult neurogenic niche $[166,211]$. In the damaged brain following hypoxia/ischemia, NSCs are resistant to glutamate toxicity, and 
Table 1 The intrinsic and extrinsic factors for the control of adult neurogenesis

\begin{tabular}{|c|c|c|c|c|c|}
\hline \multirow{2}{*}{ Factors } & & \multicolumn{3}{|c|}{ Cell types } & \multirow[t]{2}{*}{ References } \\
\hline & & NSC & Neuroblast & Immature neuron & \\
\hline \multirow[t]{6}{*}{ Growth/Neurotrophic/Morphogenic factors } & IGF-1 & SGZ & & DG & {$[53,197-199]$} \\
\hline & Insulin & SGZ & & & {$[135,180,182]$} \\
\hline & NGF & & & DG & [204] \\
\hline & BDNF & & & DG & {$[205,206]$} \\
\hline & Shh & SVZ & & & [228] \\
\hline & Wnt & $\mathrm{SGZ}$ & & & {$[226,227,230]$} \\
\hline \multirow[t]{4}{*}{ Steroid hormones } & Progesterone & & & DG & [236] \\
\hline & Estrogen & SGZ & & & [231] \\
\hline & Prolactin & & & $\mathrm{OB}$ & [234] \\
\hline & Androgen & SGZ & & DG & [232] \\
\hline \multirow[t]{5}{*}{ Neurotransmitters } & Glutamate & OB, SVZ & SVZ & DG & {$[156,166,193,211,212]$} \\
\hline & GABA & & DG & $\mathrm{OB}, \mathrm{DG}$ & {$[213-215]$} \\
\hline & Serotonin & SGZ & & DG & {$[216-218]$} \\
\hline & Dopamine & & & $\mathrm{DG}, \mathrm{OB}$ & {$[219,220]$} \\
\hline & Acetylcholine & & & $D G, O B$ & [221-225] \\
\hline
\end{tabular}

group II mGluR stimulation prevents cell death and increases the proliferation of type $\mathrm{C}$ cells by reducing cell cycle time in the SVZ [193], suggesting that glutamate also regulates NSC proliferation in this context via the activation of different receptors. SVZ-derived NPCs express functional mGlu1 and mGlu5 metabotropic glutamate receptors, and administration of mGluR1 antagonists (CPCCOEt) promotes the survival of NSCs, raising the possibility that endogenously activated mGluR1 can regulate natural cell loss by controlling the number of progenitors [212].

In the adult hippocampus, GABAergic synaptic input from parvalbumin-expressing interneurons promotes the survival of young DG neurons [213]. Suppression of GABA excitation in newborn neurons also impaired the survival of newborn neurons, a process mediated by the suppression of CREB activation [214]. Therefore, GABAmediated depolarization and the subsequent initiation of CREB signaling appear to enhance the survival rate of newborn dentate granule cells [215].

Other neurotransmitters serotonin (5-HT) [216-218], dopamine (DA) [219, 220], and acetylcholine [221] have survival-promoting activity during adult neurogenesis predominantly via 5-HT1A receptor subtype, D1-like receptor, and $\alpha 7$-containing nicotinic acetylcholine receptors, respectively [222-225].

Morphogens sonic hedgehog (Shh) and Wnt are responsible for the maintenance of the stem cell population in the adult brain [226, 227]. A loss-of-function study using transgenic $S h h^{n / c} ; N^{c r e}$ mice showed that disturbance of Shh signaling reduced the number of neurospheres formed and the mechanism of action is at least partly via regulation of $\mathrm{PCD}$ in the neurogenic region [228]. Impaired $W n t / \beta$-catenin signaling activates caspase-3 in NSCs of DG [229]. Mature dentate granule neurons in SGZ is a source of secreted molecule that regulate activation of quiescent NSCs via secreted frizzled-related protein 3 (sFRP3), which is a naturally secreted inhibitor of Wnt; loss-of-function study using adult nestin-CreER $R^{T 2}:: Z / E G^{f /+}:: s f r p 3^{-/-}$mice has shown profound increase in postmitotic cells compared to wildtype mice [230]. In addition to the above mitogenic factors, steroid hormones progesterone, estrogen [231], and androgen [232] also control adult neurogenesis. Progesterone in particular enhances neuronal survival by receptor-mediated signaling [233-236].

Clearly, dynamic changes in the levels of the various cellular factors will serve as the potential determinant for the cell death rates of NSCs, thereby the extent of neurogenesis in the adult brain. However, the detailed mechanisms by which each factor affects the PCD of NSCs are lacking in majority of the studies and there is a big gap in our understanding between the physiological outcomes of the cellular factors and their action mechanisms in regulation of adult neurogenesis.

\section{Systemic regulation of PCD in adult neurogenesis}

Considering that one of the major roles of the nervous system is to sense external information and to decode the information for behavioral/functional outcomes, it is no wonder that adult neurogenesis and the resulting brain plasticity is intimately associated with the external sensing and behavioral responses of an organism at the systemic level. It has been proposed that the proliferation 
of NSCs requires long-term lag periods to have a functional impact on brain function, because newly produced neurons require 3-6 weeks for system integration [237]. On the other hand, PCD mainly occurs $2-4$ weeks after birth, indicating that regulation of PCD can immediately regulate neurogenesis-related brain plasticity. In this respect, it is tempting to speculate that the control of NSC proliferation and $\mathrm{PCD}$ is somewhat suitable to maneuver various changes at the systemic level, such as experiencebased learning and stress, nutritional condition, and aging $[86,238]$.

\section{Experience}

It has been reported that environmental stimuli or the experience of the animal affect the extent of neurogenesis. For instance, an enriched environment or physical exercise enhances the survival of newly generated hippocampal neurons [165, 208, 239-241]. Enrichment of the odorant environment at a critical period also promotes the survival of OB neurons in mice [179, 242, 243]. On the other hand, odor deprivation by naris closure reduced neurogenesis in olfactory bulb and increased the death of the adult-generated neurons [244]. Hippocampal learning such as eye blink conditioning, a water maze task, or olfactory learning such as odor discrimination promote the survival of newly generated neurons in the DG and OB, respectively [164, 245, 246]. On the other hand, aversive experience such as stress or social defeat reduced adult neurogenesis [247, 248]. The induction of long-term potentiation, which is the cellular basis of learning and memory, also promotes the proliferation and survival of new neurons in the DG of rats [249, $250]$, suggesting that the use of neural circuits may promote the survival of new neurons. It remains unclear how neural activity ultimately controls PCD, although humoral factors, hormones, and neurotransmitters all appear to contribute to the regulation of PCD either directly or indirectly $[49,205,251-253]$. Recently, molecular links between experience-based learning and adult neurogenesis have been reported. Running, an element of environmental enrichment, increased DG neurogenesis and BDNF levels [254]. Running also induced the uptake of blood IGF-1 into the brain and peripheral infusion of anti-IGF-1 blocked running-induced increases in hippocampal neurogenesis [255]. During the development of newborn interneurons in olfactory bulb, sensory experience is a critical factor and it regulates dendritic branching and spine formation by $5 \mathrm{~T} 4$ oncofetal trophoblast glycoprotein and the neuronal Per/Arnt/Sim domain protein 4 transcription factor [256].

\section{Energy metabolism}

Adult neurogenesis is dependent on numerous stimulating and inhibiting extrinsic factors, including dietary components. There is growing evidence suggesting that neurogenesis is impaired by high-fat diet-induced and genetic forms of obesity. The excessive intake of carbohydrates and saturated fatty acids leads to obesity and alterations in neurogenesis [257]. Indeed, the link between neuropathology and obesity has been shown by demonstrating that weight reduction improves cognitive function [258].

In recent years, factors that may mediate the correlation between diet composition, obesity, and adult neurogenesis have been investigated. Among these factors, appetite-related mediators, including circulating hormones such as leptin, ghrelin, and the proinflammatory cytokine TNF- $\alpha$ are being examined to characterize their potential role in mediating neurogenic responses to macronutrients. In vitro and in vivo studies have demonstrated that leptin and ghrelin stimulate adult neurogenesis by activating receptors on newly generated neurons in the hippocampus, hypothalamus, and brainstem regions [259-261]. In addition, it has been shown that hippocampal neurogenesis is impaired in rodent models of diabetes [262]. Diabetes impairs hippocampal function through glucocorticoid-mediated effects on both new and mature neurons, and the impairment is reversed when elevated levels of circulating corticosterone are normalized. Neurogenesis in the SVZ appears to be mediated by insulin, glucocorticoids, and BDNF [263].

Neuroplasticity changes including neuronal activation, neurochemical phenotype, synaptic connections, and dendritic growth in the hypothalamus can be stimulated by dietary factors even in adulthood. This hypothalamic neurogenesis is proposed as a compensatory mechanism that regulates energy balance by replacing dead neurons [103]. Several factors, including a variety of metabolic signals known to change energy supply via nutrientsensing and satiety, may be involved in hypothalamic neurogenesis.

\section{Aging}

It is well known that the extent of adult neurogenesis is significantly associated with age, and the numbers of NSCs in most adult neurogenic regions are reduced with age [264]. For example, the proliferation of NSCs or neuroblasts in the rodent SVZ is decreased by $50-70 \%$ at 10-14 months of age [265-267], resulting in a $>80 \%$ decrease in the final number of newly produced neurons in the OB [266, 268]. Similarly, decreases in NSC proliferation and adult neurogenesis are also observed in the DG of 13 month old rodents [241]. On the other hand, the reduction in neurogenesis mainly occurs during 36 months of age in the SCZ [269], suggesting that the time-course of age-related changes in adult neurogenesis differs depending on the region of the brain. 
Although it is clear that the extent of adult neurogenesis declines with age, this spontaneous reduction in NSC number is theoretically caused by multiple events, including PCD of precursors, reduced mitotic potential, and terminal differentiation. It appears that neural progenitors terminally differentiate into astrocytic cells in the DG [270]. In addition, age-related changes in the proliferating potential of NSCs (i.e., the transition from an active to a quiescent state) is also observed in the DG [270]; these are mediated by changes in the expression of cell cycle-related genes in NSCs [271, 272]. However, the contribution of PCD to NSC loss remains unclear, mainly due to technical difficulties in investigating this issue. In addition, adult neurogenic regions are in fact complex, and proliferating cells and differentiated cells are not well segregated spatially. As molecular markers for cell type identification are often downregulated during the early phase of PCD, the specific cell types that are actually degenerating in vivo are often not easily determined.

\section{Conclusions}

In contrast to the great deal of interest in neuronal cell death during the development and pathogenesis of neurological disorders in the CNS, relatively little is known about the molecular mechanisms of PCD underlying adult neurogenesis. Adult neurogenesis continues throughout life. However, the number of mature neurons that become functional is several orders less than the number of proliferating neural precursors. Furthermore, in spite of continuous neurogenesis, the volumes of the SVZ and DG remain constant during adulthood. This means that there are cellular mechanisms working to eliminate the substantial fraction of proliferating or newborn cells and maintain the appropriate cell number in neurogenic regions.

Several critical questions need to be answered to understand the biological principles regulating this intricate balance between neurogenesis and the maintenance of total cell number in neurogenic regions. One key question is what molecular mechanism(s) is/are responsible for turnover of NSCs during adult neurogenesis. Histological and stereological studies in several genetic animal models targeting cell death molecules have suggested that the apoptotic pathways involved in neurogenesis are just beginning to be identified. However, more detailed knowledge of the molecular pathways regulating PCD of NSCs is needed for improved therapeutic design aimed at stem cell therapy. In addition, lack of knowledge of the complex interrelation between apoptosis and other non-apoptotic cell death mechanisms could be a hurdle to harnessing the possible therapeutic potential in adult neurogenesis.
Second, it remains unknown how neurogenesis is linked to the PCD-mediated elimination of "extra" new neurons. It is interesting to hypothesize that NSCs incapable of going through the destined developmental program would be doomed to removal by PCD. If this is the case, then what could the molecular trigger be for the initiation of PCD in such NSCs? Do we need a theoretical model, similar to the "neurotrophic theory", to explain the molecular events behind PCD in adult neurogenesis?

Whether differences exist in molecular mechanisms of PCD between embryonic and adult neurogenesis stages or between basal on-going PCD and PCD associated with pathological conditions during adult neurogenesis are intriguing questions. Another key question is whether each developmental stage of neurogenesis will require distinct cell death machinery and regulatory programs. For example, it is not known whether quiescent NSCs (e.g., type B progenitors in the SVG) undergo PCD. If so, it has never been asked whether there are mechanistic differences between cell death in quiescent NSCs and in the proliferating populations of NSCs. The developmental stage at which cell death occurs, and whether cells may have different propensities to undergo specific PCD programs depending on their developmental stage, will be very challenging to elucidate. To address these questions, we will need extensive comparative analyses of cell death at each developmental stage of the entire process of neurogenesis.

Finally, clinical application would be feasible if we can further elucidate the mechanism of PCD during adult neurogenesis. Because many studies have not directly measured the PCD of endogenous cells in vivo upon transplantation, potential hazards or benefits cannot be fully predicted. An understanding of the molecular mechanism underlying PCD during adult neurogenesis, which will contribute to enhancing the survival and differentiation of endogenous NSCs, will advance the clinical applications of NSC therapy.

\section{Ethics approval}

Ethics approval and consent to participate, consent for publication, and availability of data and material are not applicable to this study.

\footnotetext{
Abbreviations

5-HT: Serotonin; ACD: Autophagic cell death; BDNF: Brain-derived neurotropic factor; BrdU: Bromodeoxyuridine; Carbon-14: $C^{14}$; CNS: Central nervous system; DA: Dopamine; DCX: Doublecortin; DISC: Death-inducing signaling complex; ER: Endoplamic reticulum; FasL: Fas ligand; GABA: Gamma aminobutyric acid; HCN: Hippocampal neural stem; HGF: Hepatocyte growth factor; mGluRs: metabotropic glutamate receptors; NCAM: Neural cell

adhesion molecule; NG2: Neural/glia antigen 2; NGFs: Nerve growth factors; NMDARs: N-Methyl-D-aspartic acid receptors; NPCs: Neural progenitor cells; NSCs: Neural stem cells; NT-3: Neurotrophin-3; OB: Olfactory bulb; P2X7R: Purinergic P2X7 receptor; PCD: Programmed cell death; RGCs: Retinal ganglion cells; RIP: Receptor-interacting protein; SCZ: Subcallosal zone;
} 
SFRP3: secreted frizzled-related protein 3; SGZ: Subgranular zone; Shh: Sonic hedgehog; SVZ: Subventricular zone; TNF: Tumor necrosis factor; TRAIL: TNFrelated apoptosis-inducing ligand.

\section{Competing interests}

The authors declare that they have no competing interests.

\section{Authors' contributions}

JRR, CJH, JYK, EKK, WS and SWY analyzed the published studies and wrote the draft. WS and SWY edited and wrote the manuscript. All authors read and approved the final manuscript.

\section{Acknowledgements}

This work was supported by grants from the National Research Foundation to W. Sun (NRF 2012M3A9C604993 and NRF-2011-0019212), S.-W. Yu (NRF 2012M3A9C6049935) and E.-K. Kim (NRF 2013M3C7A1056099) and by a grant from the DGIST Convergence Science Center Program (16-BD-04) of the Ministry of Science, ICT and Future Planning of Korea to S.-W. Yu and E.-K. $\mathrm{Kim}$. The funding agencies did not play a role in the design of the study, collection, analysis and interpretation of data, and in writing the manuscript.

\section{Author details}

${ }^{1}$ Department of Anatomy, College of Medicine, Korea University, Seoul 136-705, Republic of Korea. ${ }^{2}$ Department of Brain and Cognitive Sciences, Daegu Gyeongbuk Institute of Science and Technology (DGIST), Daegu 711-873, Republic of Korea. ${ }^{3}$ Neurometabolomics Research Center, Daegu Gyeongbuk Institute of Science and Technology (DGIST), Daegu 711-873, Republic of Korea.

\section{Received: 26 February 2016 Accepted: 14 April 2016 Published online: 21 April 2016}

\section{References}

1. Buss RR, Sun W, Oppenheim RW. Adaptive roles of programmed cell death during nervous system development. Annu Rev Neurosci. 2006;29:1-35.

2. Oppenheim RW. Viktor Hamburger (1900-2001). Journey of a neuroembryologist to the end of the millennium and beyond. Neuron. 2001;31:179-90.

3. Oppenheim RW. Cell death of motoneurons in the chick embryo spinal cord. V. Evidence on the role of cell death and neuromuscular function in the formation of specific peripheral connections. J Neurosci. 1981;1:141-51.

4. Oppenheim RW, Chu-wang I. Spontaneous cell death of spinal motoneurons following peripheral innervation in the chick embryo. Brain Res. 1977:125:154-60.

5. Oppenheim RW, Prevette D, Yin QW, Collins F, MacDonald J. Control of embryonic motoneuron survival in vivo by ciliary neurotrophic factor. Science. 1991;251:1616-8

6. Cowan WM. Viktor Hamburger and Rita Levi-Montalcini: the path to the discovery of nerve growth factor. Annu Rev Neurosci. 2001;24:551-600.

7. Hamburger V. Cell death in the development of the lateral motor column of the chick embryo. J Comp Neurol. 1975;160:535-46.

8. Gage FH. Mammalian neural stem cells. Science. 2000;287:1433-8.

9. Zhao C, Deng W, Gage FH. Mechanisms and functional implications of adult neurogenesis. Cell. 2008;132:645-60

10. Lledo PM, Alonso M, Grubb MS. Adult neurogenesis and functional plasticity in neuronal circuits. Nat Rev Neurosci. 2006;7:179-93.

11. Imayoshi I, Sakamoto M, Ohtsuka T, Takao K, Miyakawa T, Yamaguchi M, Mori K, Ikeda T, Itohara S, Kageyama R. Roles of continuous neurogenesis in the structural and functional integrity of the adult forebrain. Nat Neurosci. 2008;11:1153-61.

12. Perez-Domper $\mathrm{P}$, Gradari $\mathrm{S}$, Trejo JL. The growth factors cascade and the dendrito-/synapto-genesis versus cell survival in adult hippocampal neurogenesis: the chicken or the egg. Ageing Res Rev. 2013;12:777-85.

13. Altman J, Das GD. Autoradiographic and histological evidence of postnatal hippocampal neurogenesis in rats. J Comp Neurol. 1965;124:319-35.

14. Ming GL, Song $\mathrm{H}$. Adult neurogenesis in the mammalian central nervous system. Annu Rev Neurosci. 2005;28:223-50.

15. Kuan CY, Schloemer AJ, Lu A, Burns KA, Weng WL, Williams MT, Strauss KI, Vorhees CV, Flavell RA, Davis RJ, et al. Hypoxia-ischemia induces DNA synthesis without cell proliferation in dying neurons in adult rodent brain. J Neurosci. 2004;24:10763-72.
16. Taupin P. BrdU immunohistochemistry for studying adult neurogenesis: paradigms, pitfalls, limitations, and validation. Brain Res Rev. 2007:53:198-214.

17. Price J, Turner D, Cepko C. Lineage analysis in the vertebrate nervous system by retrovirus-mediated gene transfer. Proc Natl Acad Sci U S A. 1987:84:156-60.

18. Sanes JR, Rubenstein JL, Nicolas JF. Use of a recombinant retrovirus to study post-implantation cell lineage in mouse embryos. EMBO J. 1986;5:3133-42.

19. Yan R, Zhang L, Zhang Q, Li J, Kang X, Wang H, Zhang J, Yang S, Yang X. A new finding concerning adenoviral-mediated gene transfer: a high-level, cell-specific transgene expression in the neural stem cells of adult mice. J Virol Methods. 2012;186:1-6.

20. Ge S, Goh EL, Sailor KA, Kitabatake Y, Ming GL, Song H. GABA regulates synaptic integration of newly generated neurons in the adult brain. Nature. 2006:439:589-93.

21. Ng T, Ryu JR, Sohn JH, Tan T, Song H, Ming GL, Goh EL. Class 3 semaphorin mediates dendrite growth in adult newborn neurons through Cdk5/FAK pathway. PLoS One. 2013;8:e65572.

22. Ables JL, Decarolis NA, Johnson MA, Rivera PD, Gao Z, Cooper DC, Radtke F, Hsieh J, Eisch AJ. Notch1 is required for maintenance of the reservoir of adult hippocampal stem cells. J Neurosci. 2010;30:10484-92.

23. Dranovsky A, Picchini AM, Moadel T, Sisti AC, Yamada A, Kimura S, Leonardo ED, Hen R. Experience dictates stem cell fate in the adult hippocampus. Neuron. 2011;70:908-23.

24. Kuo CT, Mirzadeh Z, Soriano-Navarro M, Rasin M, Wang D, Shen J, Sestan N, Garcia-Verdugo J, Alvarez-Buylla A, Jan LY, Jan YN. Postnatal deletion of Numb/Numblike reveals repair and remodeling capacity in the subventricular neurogenic niche. Cell. 2006;127:1253-64.

25. Petrik D, Latchney SE, Masiulis I, Yun S, Zhang Z, Wu Jl, Eisch AJ. Chromatin Remodeling Factor Brg1 Supports the Early Maintenance and Late Responsiveness of Nestin-Lineage Adult Neural Stem and Progenitor Cells. Stem Cells. 2015:33:3655-65.

26. Bergmann O, Liebl J, Bernard S, Alkass K, Yeung MS, Steier P, Kutschera W, Johnson $\mathrm{L}$, Landen $\mathrm{M}$, Druid $\mathrm{H}$. The age of olfactory bulb neurons in humans. Neuron. 2012;74:634-9.

27. Bhardwaj RD, Curtis MA, Spalding KL, Buchholz BA, Fink D, Bjork-Eriksson T, Nordborg C, Gage FH, Druid H, Eriksson PS, Frisen J. Neocortical neurogenesis in humans is restricted to development. Proc Natl Acad Sci U S A. 2006;103:12564-8.

28. Ernst A, Alkass K, Bernard S, Salehpour M, Perl S, Tisdale J, Possnert G, Druid $H$, Frisen J. Neurogenesis in the striatum of the adult human brain. Cell. 2014;156:1072-83.

29. Kreutzberg GW. Microglia: a sensor for pathological events in the CNS Trends Neurosci. 1996;19:312-8.

30. Streit WJ. Microglial response to brain injury: a brief synopsis. Toxicol Pathol. 2000;28:28-30.

31. Lu Z, Elliott MR, Chen Y, Walsh JT, Klibanov AL, Ravichandran KS, Kipnis J. Phagocytic activity of neuronal progenitors regulates adult neurogenesis. Nat Cell Biol. 2011:13:1076-83.

32. Sierra A, Encinas JM, Deudero JJ, Chancey JH, Enikolopov G, Overstreet-Wadiche LS, Tsirka SE, Maletic-Savatic M. Microglia shape adult hippocampal neurogenesis through apoptosis-coupled phagocytosis. Cell Stem Cell. 2010;7:483-95.

33. Kim WR, Kim Y, Eun B, Park OH, Kim H, Kim K, Park CH, Vinsant S, Oppenheim RW, Sun W. Impaired migration in the rostral migratory stream but spared olfactory function after the elimination of programmed cell death in Bax knock-out mice. J Neurosci. 2007;27:14392-403.

34. Kim WR, Park OH, Choi S, Choi SY, Park SK, Lee KJ, Rhyu IJ, Kim H, Lee YK, Kim HT, et al. The maintenance of specific aspects of neuronal function and behavior is dependent on programmed cell death of adult-generated neurons in the dentate gyrus. Eur J Neurosci. 2009;29:1408-21.

35. Alvarez-Buylla A, Lim DA. For the long run: maintaining germinal niches in the adult brain. Neuron. 2004:41:683-6.

36. Reh TA, Fischer AJ. Retinal stem cells. Methods Enzymol. 2006;419:52-73.

37. Seri B, Herrera DG, Gritti A, Ferron S, Collado L, Vescovi A, Garcia-Verdugo JM, Alvarez-Buylla A. Composition and organization of the SCZ: a large germinal layer containing neural stem cells in the adult mammalian brain Cereb Cortex. 2006;16 Suppl 1:1103-111.

38. Takemura NU. Evidence for neurogenesis within the white matter beneath the temporal neocortex of the adult rat brain. Neuroscience. 2005;134:121-32.

39. Hugnot JP. Isolate and culture neural stem cells from the mouse adult spinal cord. Methods Mol Biol. 2013;1059:53-63.

40. Ghashghaei HT, Lai C, Anton ES. Neuronal migration in the adult brain: are we there yet? Nat Rev Neurosci. 2007;8:141-51. 
41. Snapyan M, Lemasson M, Brill MS, Blais M, Massouh M, Ninkovic J, Gravel C, Berthod F, Gotz M, Barker PA, et al. Vasculature guides migrating neuronal precursors in the adult mammalian forebrain via brain-derived neurotrophic factor signaling. J Neurosci. 2009;29:4172-88.

42. Whitman MC, Fan W, Rela L, Rodriguez-Gil DJ, Greer CA. Blood vessels form a migratory scaffold in the rostral migratory stream. J Comp Neurol. 2009; 516:94-104.

43. Lledo PM, Saghatelyan A. Integrating new neurons into the adult olfactory bulb: joining the network, life-death decisions, and the effects of sensory experience. Trends Neurosci. 2005;28:248-54.

44. Platel JC, Stamboulian S, Nguyen I, Bordey A. Neurotransmitter signaling in postnatal neurogenesis: The first leg. Brain Res Rev. 2010;63:60-71.

45. Garzotto D, Giacobini P, Crepaldi T, Fasolo A, De Marchis S. Hepatocyte growth factor regulates migration of olfactory interneuron precursors in the rostral migratory stream through Met-Grb2 coupling. J Neurosci. 2008;28: 5901-9.

46. Wang TW, Zhang H, Gyetko MR, Parent JM. Hepatocyte growth factor acts as a mitogen and chemoattractant for postnatal subventricular zoneolfactory bulb neurogenesis. Mol Cell Neurosci. 2011:48:38-50.

47. Biebl M, Cooper CM, Winkler J, Kuhn HG. Analysis of neurogenesis and programmed cell death reveals a self-renewing capacity in the adult rat brain. Neurosci Lett. 2000;291:17-20.

48. Lois C, Alvarez-Buylla A. Long-distance neuronal migration in the adult mammalian brain. Science. 1994;264:1145-8.

49. Winner B, Cooper-Kuhn CM, Aigner R, Winkler J, Kuhn HG. Long-term survival and cell death of newly generated neurons in the adult rat olfactory bulb. Eur J Neurosci. 2002;16:1681-9.

50. Petreanu L, Alvarez-Buylla A. Maturation and death of adult-born olfactory bulb granule neurons: role of olfaction. J Neurosci. 2002;22:6106-13.

51. Bath KG, Lee FS. Neurotrophic factor control of adult SVZ neurogenesis. Dev Neurobiol. 2010;70:339-49.

52. Hurtado-Chong A, Yusta-Boyo MJ, Vergano-Vera E, Bulfone A, de Pablo F, Vicario-Abejon C. IGF-I promotes neuronal migration and positioning in the olfactory bulb and the exit of neuroblasts from the subventricular zone. Eur J Neurosci. 2009;30:742-55.

53. Aberg ND, Johansson I, Aberg MA, Lind J, Johansson UE, Cooper-Kuhn CM, Kuhn $\mathrm{HG}$, Isgaard J. Peripheral administration of $\mathrm{GH}$ induces cell proliferation in the brain of adult hypophysectomized rats. J Endocrinol. 2009;201:141-50.

54. Decressac M, Prestoz L, Veran J, Cantereau A, Jaber M, Gaillard A. Neuropeptide Y stimulates proliferation, migration and differentiation of neural precursors from the subventricular zone in adult mice. Neurobiol Dis. 2009;34:441-9.

55. Stanic D, Paratcha G, Ledda F, Herzog H, Kopin AS, Hokfelt T. Peptidergic influences on proliferation, migration, and placement of neural progenitors in the adult mouse forebrain. Proc Natl Acad Sci U S A. 2008;105:3610-5.

56. Kim WR, Sun W. Enhanced odor discrimination learning in aged Bax-KO mice. Neurosci Lett. 2013;548:196-200.

57. Sakamoto M, leki N, Miyoshi G, Mochimaru D, Miyachi H, Imura T, Yamaguchi M, Fishell G, Mori K, Kageyama R, Imayoshi I. Continuous postnatal neurogenesis contributes to formation of the olfactory bulb neural circuits and flexible olfactory associative learning. J Neurosci. 2014;34:5788-99.

58. Sakamoto M, Kageyama R, Imayoshi I. The functional significance of newly born neurons integrated into olfactory bulb circuits. Front Neurosci. 2014;8:121.

59. Feierstein CE, Lazarini F, Wagner S, Gabellec MM, de Chaumont F, OlivoMarin JC, Boussin FD, Lledo PM, Gheusi G. Disruption of Adult Neurogenesis in the Olfactory Bulb Affects Social Interaction but not Maternal Behavior. Front Behav Neurosci. 2010;4:176.

60. Gonzalez-Perez O. Neural stem cells in the adult human brain. Biological and biomedical reports. 2012;2:59-69.

61. Quinones-Hinojosa A, Sanai N, Soriano-Navarro M, Gonzalez-Perez O, Mirzadeh Z, Gil-Perotin S, Romero-Rodriguez R, Berger MS, Garcia-Verdugo JM, Alvarez-Buylla A. Cellular composition and cytoarchitecture of the adult human subventricular zone: a niche of neural stem cells. J Comp Neurol. 2006:494:415-34.

62. Sanai N, Tramontin AD, Quinones-Hinojosa A, Barbaro NM, Gupta N, Kunwar S, Lawton MT, McDermott MW, Parsa AT, Manuel-Garcia Verdugo J, et al. Unique astrocyte ribbon in adult human brain contains neural stem cells but lacks chain migration. Nature. 2004;427:740-4.

63. Curtis MA, Kam M, Nannmark U, Anderson MF, Axell MZ, Wikkelso C, Holtas S, van Roon-Mom WM, Bjork-Eriksson T, Nordborg C, et al. Human neuroblasts migrate to the olfactory bulb via a lateral ventricular extension. Science. 2007;315:1243-9.
64. Sanai N, Berger MS, Garcia-Verdugo JM, Alvarez-Buylla A. Comment on "Human neuroblasts migrate to the olfactory bulb via a lateral ventricular extension". Science. 2007;318:393. author reply 393.

65. Gu Y, Arruda-Carvalho M, Wang J, Janoschka SR, Josselyn SA, Frankland PW, Ge S. Optical controlling reveals time-dependent roles for adult-born dentate granule cells. Nat Neurosci. 2012;15:1700-6.

66. van Praag H, Schinder AF, Christie BR, Toni N, Palmer TD, Gage FH. Functional neurogenesis in the adult hippocampus. Nature. 2002;415:1030-4.

67. Zhou M, Li W, Huang S, Song J, Kim JY, Tian X, Kang E, Sano Y, Liu C, Balaji J, et al mTOR Inhibition ameliorates cognitive and affective deficits caused by Disc1 knockdown in adult-born dentate granule neurons. Neuron. 2013;77:647-54.

68. Kumamoto N, Gu Y, Wang J, Janoschka S, Takemaru K, Levine J, Ge S. A role for primary cilia in glutamatergic synaptic integration of adult-born neurons. Nat Neurosci. 2012;15:399-405. S391.

69. Fitzsimons CP, van Hooijdonk LW, Schouten M, Zalachoras I, Brinks V, Zheng T, Schouten TG, Saaltink DJ, Dijkmans T, Steindler DA, et al. Knockdown of the glucocorticoid receptor alters functional integration of newborn neurons in the adult hippocampus and impairs fear-motivated behavior. Mol Psychiatry. 2013;18:993-1005.

70. Brandt MD, Maass A, Kempermann G, Storch A. Physical exercise increases Notch activity, proliferation and cell cycle exit of type-3 progenitor cells in adult hippocampal neurogenesis. Eur J Neurosci. 2010;32:1256-64.

71. Podda MV, Leone L, Barbati SA, Mastrodonato A, Li Puma DD, Piacentini R, Grassi C. Extremely low-frequency electromagnetic fields enhance the survival of newborn neurons in the mouse hippocampus. Eur J Neurosci. 2014;39:893-903.

72. Dayer AG, Ford AA, Cleaver KM, Yassaee M, Cameron HA. Short-term and long-term survival of new neurons in the rat dentate gyrus. J Comp Neurol. 2003;460:563-72.

73. Sun W, Winseck A, Vinsant S, Park OH, Kim H, Oppenheim RW. Programmed cell death of adult-generated hippocampal neurons is mediated by the proapoptotic gene Bax. J Neurosci. 2004;24:11205-13.

74. Spalding KL, Bergmann O, Alkass K, Bernard S, Salehpour M, Huttner HB, Bostrom E, Westerlund I, Vial C, Buchholz BA, et al. Dynamics of hippocampal neurogenesis in adult humans. Cell. 2013;153:1219-27.

75. Kim WR, Chun SK, Kim TW, Kim H, Ono K, Takebayashi H, Ikenaka K, Oppenheim RW, Sun W. Evidence for the spontaneous production but massive programmed cell death of new neurons in the subcallosal zone of the postnatal mouse brain. Eur J Neurosci. 2011;33:599-611.

76. Jovanov-Milosevic N, Petanjek Z, Petrovic D, Judas M, Kostovic I. Morphology, molecular phenotypes and distribution of neurons in developing human corpus callosum. Eur J Neurosci. 2010;32:1423-32.

77. Roy NS, Wang S, Harrison-Restelli C, Benraiss A, Fraser RA, Gravel M, Braun PE, Goldman SA. Identification, isolation, and promoter-defined separation of mitotic oligodendrocyte progenitor cells from the adult human subcortical white matter. J Neurosci. 1999;19:9986-95.

78. Nunes MC, Roy NS, Keyoung HM, Goodman RR, McKhann 2nd G, Jiang L, Kang J, Nedergaard M, Goldman SA. Identification and isolation of multipotential neural progenitor cells from the subcortical white matter of the adult human brain. Nat Med. 2003;9:439-47.

79. Dayer AG, Cleaver KM, Abouantoun T, Cameron HA. New GABAergic interneurons in the adult neocortex and striatum are generated from different precursors. J Cell Biol. 2005;168:415-27.

80. Huang L, DeVries GJ, Bittman EL. Photoperiod regulates neuronal bromodeoxyuridine labeling in the brain of a seasonally breeding mammal. J Neurobiol. 1998;36:410-20.

81. Gould E, Reeves AJ, Graziano MS, Gross CG. Neurogenesis in the neocortex of adult primates. Science. 1999;286:548-52.

82. Gould E, Vail N, Wagers M, Gross CG. Adult-generated hippocampal and neocortical neurons in macaques have a transient existence. Proc Natl Acad Sci U S A. 2001;98:10910-7.

83. Koketsu D, Mikami A, Miyamoto Y, Hisatsune T. Nonrenewal of neurons in the cerebral neocortex of adult macaque monkeys. J Neurosci. 2003;23:937-42.

84. Kornack DR, Rakic P. Cell proliferation without neurogenesis in adult primate neocortex. Science. 2001;294:2127-30.

85. Magavi SS, Leavitt BR, Macklis JD. Induction of neurogenesis in the neocortex of adult mice. Nature. 2000;405:951-5.

86. Gould E, Beylin A, Tanapat P, Reeves A, Shors TJ. Learning enhances adult neurogenesis in the hippocampal formation. Nat Neurosci. 1999;2:260-5.

87. Gould E. How widespread is adult neurogenesis in mammals? Nat Rev Neurosci. 2007;8:481-8. 
88. Weiss S, Dunne C, Hewson J, Wohl C, Wheatley M, Peterson AC, Reynolds BA. Multipotent CNS stem cells are present in the adult mammalian spina cord and ventricular neuroaxis. J Neurosci. 1996;16:7599-609.

89. Ohori Y, Yamamoto S, Nagao M, Sugimori M, Yamamoto N, Nakamura K, Nakafuku M. Growth factor treatment and genetic manipulation stimulate neurogenesis and oligodendrogenesis by endogenous neural progenitors in the injured adult spinal cord. J Neurosci. 2006;26:11948-60.

90. Yamamoto S, Yamamoto N, Kitamura T, Nakamura K, Nakafuku M. Proliferation of parenchymal neural progenitors in response to injury in the adult rat spinal cord. Exp Neurol. 2001;172:115-27.

91. Fiorelli R, Cebrian-Silla A, Garcia-Verdugo JM, Raineteau O. The adult spinal cord harbors a population of GFAP-positive progenitors with limited selfrenewal potential. Glia. 2013;61:2100-13.

92. Hamilton LK, Truong MK, Bednarczyk MR, Aumont A, Fernandes KJ. Cellular organization of the central canal ependymal zone, a niche of latent neural stem cells in the adult mammalian spinal cord. Neuroscience. 2009;164:1044-56.

93. Meletis K, Barnabe-Heider F, Carlen M, Evergren E, Tomilin N, Shupliakov O, Frisen J. Spinal cord injury reveals multilineage differentiation of ependymal cells. PLoS Biol. 2008;6:e182.

94. Sabelstrom H, Stenudd M, Frisen J. Neural stem cells in the adult spinal cord. Exp Neurol. 2014;260:44-9.

95. Alcock J, Scotting P, Sottile V. Bergmann glia as putative stem cells of the mature cerebellum. Med Hypotheses. 2007;69:341-5.

96. Lee A, Kessler JD, Read TA, Kaiser C, Corbeil D, Huttner WB, Johnson JE, Wechsler-Reya RJ. Isolation of neural stem cells from the postnatal cerebellum. Nat Neurosci. 2005;8:723-9.

97. Klein C, Butt SJ, Machold RP, Johnson JE, Fishell G. Cerebellum- and forebrain-derived stem cells possess intrinsic regional character. Development. 2005;132:4497-508.

98. Fischer AJ, Reh TA. Potential of Muller glia to become neurogenic retinal progenitor cells. Glia. 2003;43:70-6.

99. Braisted JE, Essman TF, Raymond PA. Selective regeneration of photoreceptors in goldfish retina. Development. 1994;120:2409-19.

100. Chetty S, Friedman AR, Taravosh-Lahn K, Kirby ED, Mirescu C, Guo F, Krupik D, Nicholas A, Geraghty AC, Krishnamurthy A, et al. Stress and glucocorticoids promote oligodendrogenesis in the adult hippocampus. Mol Psychiatry. 2014;19(12):1275-83.

101. Del Debbio CB, Peng X, Xiong H, Ahmad I. Adult ciliary epithelial stem cells generate functional neurons and differentiate into both early and late born retinal neurons under non-cell autonomous influences. BMC Neurosci. 2013; $14: 130$.

102. Kokoeva MV, Yin H, Flier JS. Neurogenesis in the hypothalamus of adult mice: potential role in energy balance. Science. 2005;310:679-83.

103. Pierce $A A, X u A W$. De novo neurogenesis in adult hypothalamus as a compensatory mechanism to regulate energy balance. J Neurosci. 2010;30: 723-30.

104. Lee DA, Bedont JL, Pak T, Wang H, Song J, Miranda-Angulo A, Takiar V, Charubhumi V, Balordi F, Takebayashi H, et al. Tanycytes of the hypothalamic median eminence form a diet-responsive neurogenic niche. Nat Neurosci. 2012;15:700-2.

105. Lee DA, Yoo S, Pak T, Salvatierra J, Velarde E, Aja S, Blackshaw S. Dietary and sex-specific factors regulate hypothalamic neurogenesis in young adult mice. Front Neurosci. 2014;8:157.

106. Pencea V, Bingaman KD, Wiegand SJ, Luskin MB. Infusion of brain-derived neurotrophic factor into the lateral ventricle of the adult rat leads to new neurons in the parenchyma of the striatum, septum, thalamus, and hypothalamus. J Neurosci. 2001;21:6706-17.

107. Zhao M, Momma S, Delfani K, Carlen M, Cassidy RM, Johansson CB, Brismar H, Shupliakov O, Frisen J, Janson AM. Evidence for neurogenesis in the adult mammalian substantia nigra. Proc Natl Acad Sci U S A. 2003;100:7925-30.

108. Frielingsdorf $H$, Schwarz K, Brundin P, Mohapel P. No evidence for new dopaminergic neurons in the adult mammalian substantia nigra. Proc Nat Acad Sci U S A. 2004;101:10177-82

109. Shan X, Chi L, Bishop M, Luo C, Lien L, Zhang Z, Liu R. Enhanced de novo neurogenesis and dopaminergic neurogenesis in the substantia nigra of 1 methyl-4-phenyl-1,2,3,6-tetrahydropyridine-induced Parkinson's disease-like mice. Stem Cells. 2006;24:1280-7.

110. Codega P, Silva-Vargas V, Paul A, Maldonado-Soto AR, Deleo AM, Pastrana E, Doetsch F. Prospective identification and purification of quiescent adult neural stem cells from their in vivo niche. Neuron. 2014;82:545-59.
111. Kerr JF, Wyllie AH, Currie AR. Apoptosis: a basic biological phenomenon with wide-ranging implications in tissue kinetics. Br J Cancer. 1972;26:239-57.

112. Kroemer G, Galluzzi L, Vandenabeele P, Abrams J, Alnemri ES, Baehrecke EH, Blagosklonny MV, El-Deiry WS, Golstein P, Green DR, et al. Classification of cell death: recommendations of the Nomenclature Committee on Cell Death 2009. Cell Death Differ. 2009;16:3-11.

113. Bleicken S, Landeta O, Landajuela A, Basanez G, Garcia-Saez AJ. Proapoptotic Bax and Bak proteins form stable protein-permeable pores of tunable size. J Biol Chem. 2013;288:33241-52.

114. Zou H, Li Y, Liu X, Wang X. An APAF-1.cytochrome c multimeric complex is a functional apoptosome that activates procaspase-9. J Biol Chem. 1999;274: 11549-56.

115. Gorman AM, Ceccatelli S, Orrenius S. Role of mitochondria in neuronal apoptosis. Dev Neurosci. 2000;22:348-58.

116. Elmore S. Apoptosis: a review of programmed cell death. Toxicol Pathol. 2007;35:495-516.

117. Gavathiotis E, Suzuki M, Davis ML, Pitter K, Bird GH, Katz SG, Tu HC, Kim H, Cheng EH, Tjandra N, Walensky LD. BAX activation is initiated at a novel interaction site. Nature. 2008:455:1076-81.

118. Czabotar PE, Westphal D, Dewson G, Ma S, Hockings C, Fairlie WD, Lee EF, Yao S, Robin AY, Smith BJ, et al. Bax crystal structures reveal how BH3 domains activate Bax and nucleate its oligomerization to induce apoptosis. Cell. 2013;152:519-31.

119. Daugas E, Susin SA, Zamzami N, Ferri KF, Irinopoulou T, Larochette N, Prevost MC, Leber B, Andrews D, Penninger J, Kroemer G. Mitochondrio-nuclear translocation of AIF in apoptosis and necrosis. FASEB J. 2000;14:729-39.

120. Kischkel FC, Lawrence DA, Chuntharapai A, Schow P, Kim KJ, Ashkenazi A. Apo2L/TRAlL-dependent recruitment of endogenous FADD and caspase-8 to death receptors 4 and 5. Immunity. 2000;12:611-20.

121. Yang Z, Klionsky DJ. Eaten alive: a history of macroautophagy. Nat Cell Biol. 2010;12:814-22.

122. De Duve C, Wattiaux R. Functions of lysosomes. Annu Rev Physiol. 1966;28: 435-92.

123. Mizushima N, Yoshimori T, Levine B. Methods in mammalian autophagy research. Cell. 2010;140:313-26.

124. Denton D, Nicolson S, Kumar S. Cell death by autophagy: facts and apparent artefacts. Cell Death Differ. 2012;19:87-95.

125. Tsujimoto Y, Shimizu S. Another way to die: autophagic programmed cell death. Cell Death Differ. 2005;12 Suppl 2:1528-34.

126. Shen HM, Codogno P. Autophagic cell death: Loch Ness monster or endangered species? Autophagy. 2011;7:457-65.

127. Kawahara A, Ohsawa Y, Matsumura H, Uchiyama Y, Nagata S. Caspaseindependent cell killing by Fas-associated protein with death domain. J Cell Biol. 1998;143:1353-60.

128. Degterev A, Hitomi J, Germscheid M, Ch'en IL, Korkina O, Teng X, Abbott D, Cuny GD, Yuan C, Wagner G, et al. Identification of RIP1 kinase as a specific cellular target of necrostatins. Nat Chem Biol. 2008:4:313-21.

129. Golstein P, Kroemer G. Cell death by necrosis: towards a molecular definition. Trends Biochem Sci. 2007:32:37-43.

130. Leist M, Single B, Castoldi AF, Kuhnle S, Nicotera P. Intracellular adenosine triphosphate (ATP) concentration: a switch in the decision between apoptosis and necrosis. J Exp Med. 1997;185:1481-6.

131. Pieper AA, Xie S, Capota E, Estill SJ, Zhong J, Long JM, Becker GL, Huntington P, Goldman SE, Shen $\mathrm{CH}$, et al. Discovery of a proneurogenic, neuroprotective chemical. Cell. 2010;142:39-51.

132. Palmer TD, Ray J, Gage FH. FGF-2-responsive neuronal progenitors reside in proliferative and quiescent regions of the adult rodent brain. Mol Cell Neurosci. 1995;6:474-86

133. Malone CD, Hasan SM, Roome RB, Xiong J, Furlong M, Opferman JT, Vanderluit JL. Mcl-1 regulates the survival of adult neural precursor cells. Mol Cell Neurosci. 2012;49:439-47.

134. Lindsten T, Golden JA, Zong WX, Minarcik J, Harris MH, Thompson CB. The proapoptotic activities of Bax and Bak limit the size of the neural stem cell pool. J Neurosci. 2003:23:11112-9.

135. Yu SW, Baek SH, Brennan RT, Bradley CJ, Park SK, Lee YS, Jun EJ, Lookingland KJ, Kim EK, Lee H, et al. Autophagic death of adult hippocampal neural stem cells following insulin withdrawal. Stem Cells. 2008;26:2602-10.

136. Bunk EC, Konig HG, Bernas T, Engel T, Henshall DC, Kirby BP, Prehn JH. BH3only proteins BIM and PUMA in the regulation of survival and neuronal differentiation of newly generated cells in the adult mouse hippocampus. Cell death \& disease. 2010;1:e15. 
137. Fatt MP, Cancino GI, Miller FD, Kaplan DR. p63 and p73 coordinate p53 function to determine the balance between survival, cell death, and senescence in adult neural precursor cells. Cell Death Differ. 2014;21: 1546-59.

138. Liu D, Ou L, Clemenson Jr GD, Chao C, Lutske ME, Zambetti GP, Gage FH, Xu Y. Puma is required for p53-induced depletion of adult stem cells. Nat Cell Biol. 2010;12:993-8.

139. Gil-Perotin S, Marin-Husstege M, Li J, Soriano-Navarro M, Zindy F, Roussel MF, Garcia-Verdugo JM, Casaccia-Bonnefil P. Loss of p53 induces changes in the behavior of subventricular zone cells: implication for the genesis of glial tumors. J Neurosci. 2006;26:1107-16.

140. van Lookeren Campagne M, Gill R. Tumor-suppressor p53 is expressed in proliferating and newly formed neurons of the embryonic and postnatal rat brain: comparison with expression of the cell cycle regulators p21Waf1/ Cip1, p27Kip1, p57Kip2, p16Ink4a, cyclin G1, and the proto-oncogene Bax. J Comp Neurol. 1998;397:181-98.

141. Amson R, Lassalle JM, Halley H, Prieur S, Lethrosne F, Roperch JP, Israeli D, Gendron MC, Duyckaerts C, Checler F, et al. Behavioral alterations associated with apoptosis and down-regulation of presenilin 1 in the brains of p53deficient mice. Proc Natl Acad Sci U S A. 2000;97:5346-50.

142. Rowland AA, Voeltz GK. Endoplasmic reticulum-mitochondria contacts: function of the junction. Nat Rev Mol Cell Biol. 2012;13:607-25.

143. De Stefani D, Bononi A, Romagnoli A, Messina A, De Pinto V, Pinton P, Rizzuto R. VDAC1 selectively transfers apoptotic Ca2+ signals to mitochondria. Cell Death Differ. 2012;19:267-73.

144. Marchi S, Marinello M, Bononi A, Bonora M, Giorgi C, Rimessi A, Pinton P. Selective modulation of subtype III IP(3)R by Akt regulates ER $\mathrm{Ca}(2)(+)$ release and apoptosis. Cell Death Dis. 2012;3:e304.

145. Scorrano L, Oakes SA, Opferman JT, Cheng EH, Sorcinelli MD, Pozzan T, Korsmeyer SJ. BAX and BAK regulation of endoplasmic reticulum Ca2+: a control point for apoptosis. Science. 2003;300:135-9.

146. Bassik MC, Scorrano L, Oakes SA, Pozzan T, Korsmeyer SJ. Phosphorylation of BCL-2 regulates ER Ca2+ homeostasis and apoptosis. EMBO J. 2004;23:1207-16.

147. Shi J, Parada LF, Kernie SG. Bax limits adult neural stem cell persistence through caspase and IP3 receptor activation. Cell Death Differ. 2005;12:1601-12.

148. Martin-Villalba A, Herr I, Jeremias I, Hahne M, Brandt R, Vogel J, Schenkel J, Herdegen T, Debatin KM. CD95 ligand (Fas-L/APO-1 L) and tumor necrosis factor-related apoptosis-inducing ligand mediate ischemia-induced apoptosis in neurons. J Neurosci. 1999;19:3809-17.

149. Knight JC, Scharf EL, Mao-Draayer Y. Fas activation increases neural progenitor cell survival. J Neurosci Res. 2010;88:746-57.

150. Ceccatelli S, Tamm C, Sleeper E, Orrenius S. Neural stem cells and cell death. Toxicol Lett. 2004;149:59-66.

151. Widera D, Mikenberg I, Elvers M, Kaltschmidt C, Kaltschmidt B. Tumor necrosis factor alpha triggers proliferation of adult neural stem cells via IKK NF-kappaB signaling. BMC Neurosci. 2006;7:64

152. Covacu R, Arvidsson L, Andersson A, Khademi M, Erlandsson-Harris H, Harris RA, Svensson MA, Olsson T, Brundin L. TLR activation induces TNF-alpha production from adult neural stem/progenitor cells. J Immunol. 2009;182: 6889-95.

153. Ricci-Vitiani L, Pedini F, Mollinari C, Condorelli G, Bonci D, Bez A, Colombo A, Parati E, Peschle C, De Maria R. Absence of caspase 8 and high expression of PED protect primitive neural cells from cell death. J Exp Med. 2004;200:1257-66.

154. Jung AR, Kim TW, Rhyu IJ, Kim H, Lee YD, Vinsant S, Oppenheim RW, Sun W. Misplacement of Purkinje cells during postnatal development in Bax knockout mice: a novel role for programmed cell death in the nervous system? J Neurosci. 2008;28:2941-8.

155. Kuhn HG, Winkler J, Kempermann G, Thal L, Gage FH. Epidermal growth factor and fibroblast growth factor-2 have different effects on neural progenitors in the adult rat brain. J Neurosci. 1997;17:5820-9.

156. Platel JC, Dave KA, Gordon V, Lacar B, Rubio ME, Bordey A. NMDA receptors activated by subventricular zone astrocytic glutamate are critical for neuroblast survival prior to entering a synaptic network. Neuron. 2010; 65:859-72.

157. Lafourcade CA, Lin TV, Feliciano DM, Zhang L, Hsieh LS, Bordey A. Rheb activation in subventricular zone progenitors leads to heterotopia, ectopic neuronal differentiation, and rapamycin-sensitive olfactory micronodules and dendrite hypertrophy of newborn neurons. J Neurosci. 2013; 33:2419-31.

158. Brandt MD, Jessberger S, Steiner B, Kronenberg G, Reuter K, Bick-Sander A, von der Behrens W, Kempermann G. Transient calretinin expression defines early postmitotic step of neuronal differentiation in adult hippocampal neurogenesis of mice. Mol Cell Neurosci. 2003;24:603-13.

159. Francis JS, Dragunow M, During MJ. Over expression of ATF-3 protects rat hippocampal neurons from in vivo injection of kainic acid. Brain Res Mol Brain Res. 2004;124:199-203.

160. Nacher J, Rosell DR, Alonso-Llosa G, McEwen BS. NMDA receptor antagonist treatment induces a long-lasting increase in the number of proliferating cells, PSA-NCAM-immunoreactive granule neurons and radial glia in the adult rat dentate gyrus. Eur J Neurosci. 2001;13:512-20.

161. Belvindrah R, Rougon G, Chazal G. Increased neurogenesis in adult mCD24deficient mice. J Neurosci. 2002:22:3594-607.

162. Buss RR, Gould TW, Ma J, Vinsant S, Prevette D, Winseck A, Toops KA, Hammarback JA, Smith TL, Oppenheim RW. Neuromuscular development in the absence of programmed cell death: phenotypic alteration of motoneurons and muscle. J Neurosci. 2006:26:13413-27.

163. Vivar C, Potter MC, van Praag H. All about running: synaptic plasticity, growth factors and adult hippocampal neurogenesis. Curr Top Behav Neurosci. 2013;15:189-210.

164. Leuner B, Mendolia-Loffredo S, Kozorovitskiy Y, Samburg D, Gould E, Shors TJ. Learning enhances the survival of new neurons beyond the time when the hippocampus is required for memory. J Neurosci. 2004;24:7477-81.

165. van Praag H, Kempermann G, Gage FH. Running increases cell proliferation and neurogenesis in the adult mouse dentate gyrus. Nat Neurosci. 1999;2:266-70.

166. Tashiro A, Sandler VM, Toni N, Zhao C, Gage FH. NMDA-receptor-mediated, cell-specific integration of new neurons in adult dentate gyrus. Nature. 2006;442:929-33.

167. Hastings NB, Gould E. Rapid extension of axons into the CA3 region by adult-generated granule cells. J Comp Neurol. 1999;413:146-54

168. Markakis EA, Gage FH. Adult-generated neurons in the dentate gyrus send axonal projections to field CA3 and are surrounded by synaptic vesicles. J Comp Neurol. 1999:406:449-60.

169. Zhao C, Teng EM, Summers Jr RG, Ming GL, Gage FH. Distinct morphological stages of dentate granule neuron maturation in the adult mouse hippocampus. J Neurosci. 2006;26:3-11.

170. Belluzzi O, Benedusi M, Ackman J, LoTurco JJ. Electrophysiological differentiation of new neurons in the olfactory bulb. J Neurosci. 2003;23: 10411-8.

171. Carleton A, Petreanu LT, Lansford R, Alvarez-Buylla A, Lledo PM. Becoming a new neuron in the adult olfactory bulb. Nat Neurosci. 2003;6:507-18.

172. Wang S, Scott BW, Wojtowicz JM. Heterogenous properties of dentate granule neurons in the adult rat. J Neurobiol. 2000;42:248-57.

173. Sun W, Gould TW, Vinsant S, Prevette D, Oppenheim RW. Neuromuscular development after the prevention of naturally occurring neuronal death by Bax deletion. J Neurosci. 2003;23:7298-310.

174. Sahay A, Scobie KN, Hill AS, O'Carroll CM, Kheirbek MA, Burghardt NS, Fenton AA, Dranovsky A, Hen R. Increasing adult hippocampal neurogenesis is sufficient to improve pattern separation. Nature. 2011;472:466-70.

175. Snyder JS, Kee N, Wojtowicz JM. Effects of adult neurogenesis on synaptic plasticity in the rat dentate gyrus. J Neurophysiol. 2001;85:2423-31.

176. Esposito MS, Piatti VC, Laplagne DA, Morgenstern NA, Ferrari CC, Pitossi FJ, Schinder AF. Neuronal differentiation in the adult hippocampus recapitulates embryonic development. J Neurosci. 2005;25:10074-86.

177. Tozuka Y, Fukuda S, Namba T, Seki T, Hisatsune T. GABAergic excitation promotes neuronal differentiation in adult hippocampal progenitor cells. Neuron. 2005:47:803-15

178. Lee JW, Kim WR, Sun W, Jung MW. Disruption of dentate gyrus blocks effect of visual input on spatial firing of CA1 neurons. J Neurosci. 2012;32:12999-3003.

179. Yamaguchi M, Mori K. Critical period for sensory experience-dependent survival of newly generated granule cells in the adult mouse olfactory bulb. Proc Natl Acad Sci U S A. 2005:102:9697-702.

180. Ha S, Ryu HY, Chung KM, Baek SH, Kim EK, Yu SW. Regulation of autophagic cell death by glycogen synthase kinase-3beta in adult hippocampal neural stem cells following insulin withdrawal. Mol Brain. 2015:8:30.

181. Xia HG, Zhang L, Chen G, Zhang T, Liu J, Jin M, Ma X, Ma D, Yuan J. Control of basal autophagy by calpain1 mediated cleavage of ATG5. Autophagy. 2010;6:61-6

182. Chung KM, Park H, Jung S, Ha S, Yoo SJ, Woo H, Lee HJ, Kim SW, Kim EK, Moon C, Yu SW. Calpain determines the propensity of adult Hippocampal neural stem cells to autophagic cell death following insulin withdrawal. Stem Cells. 2015;33(10):3052-64. 
183. Yazdankhah M, Farioli-Vecchioli S, Tonchev AB, Stoykova A, Cecconi F. The autophagy regulators Ambra1 and Beclin 1 are required for adult neurogenesis in the brain subventricular zone. Cell death \& disease. 2014:5:e1403.

184. Fields RD, Burnstock $G$. Purinergic signalling in neuron-glia interactions. Nat Rev Neurosci. 2006;7:423-36.

185. Zheng LM, Zychlinsky A, Liu CC, Ojcius DM, Young JD. Extracellular ATP as a trigger for apoptosis or programmed cell death. J Cell Biol. 1991; $112: 279-88$.

186. Jun DJ, Kim J, Jung SY, Song R, Noh JH, Park YS, Ryu SH, Kim JH, Kong YY, Chung JM, Kim KT. Extracellular ATP mediates necrotic cell swelling in SN4741 dopaminergic neurons through P2X7 receptors. J Biol Chem. 2007; 282:37350-8.

187. Messemer N, Kunert C, Grohmann M, Sobottka H, Nieber K, Zimmermann H, Franke H, Norenberg W, Straub I, Schaefer M, et al. P2X7 receptors at adult neural progenitor cells of the mouse subventricular zone. Neuropharmacology. 2013;73:122-37.

188. Delarasse C, Gonnord P, Galante M, Auger R, Daniel H, Motta I, Kanellopoulos JM. Neural progenitor cell death is induced by extracellular ATP via ligation of P2X7 receptor. J Neurochem. 2009;109:846-57.

189. Suh H, Deng W, Gage FH. Signaling in adult neurogenesis. Annu Rev Cell Dev Biol. 2009;25:253-75.

190. Ming GL, Song H. Adult neurogenesis in the mammalian brain: significant answers and significant questions. Neuron. 2011;70:687-702.

191. Ihrie RA, Alvarez-Buylla A. Lake-front property: a unique germinal niche by the lateral ventricles of the adult brain. Neuron. 2011;70:674-86.

192. Tavazoie M, Van der Veken L, Silva-Vargas V, Louissaint M, Colonna L, Zaidi B, Garcia-Verdugo JM, Doetsch F. A specialized vascular niche for adult neural stem cells. Cell Stem Cell. 2008;3:279-88.

193. Brazel CY, Nunez JL, Yang Z, Levison SW. Glutamate enhances survival and proliferation of neural progenitors derived from the subventricular zone. Neuroscience. 2005;131:55-65.

194. Sierra A, Martin-Suarez S, Valcarcel-Martin R, Pascual-Brazo J, Aelvoet SA, Abiega O, Deudero JJ, Brewster AL, Bernales I, Anderson AE, et al. Neuronal hyperactivity accelerates depletion of neural stem cells and impairs hippocampal neurogenesis. Cell Stem Cell. 2015;16:488-503.

195. O'Neill C, Kiely AP, Coakley MF, Manning S, Long-Smith CM. Insulin and IGF-1 signalling: longevity, protein homoeostasis and Alzheimer's disease. Biochem Soc Trans. 2012;40:721-7.

196. Bassil F, Fernagut PO, Bezard E, Meissner WG. Insulin, IGF-1 and GLP-1 signaling in neurodegenerative disorders: targets for disease modification? Prog Neurobiol. 2014;118:1-18.

197. Anderson MF, Aberg MA, Nilsson M, Eriksson PS. Insulin-like growth factor-I and neurogenesis in the adult mammalian brain. Brain Res Dev Brain Res. 2002;134:115-22

198. O'Kusky JR, Ye P, D'Ercole AJ. Insulin-like growth factor-I promotes neurogenesis and synaptogenesis in the hippocampal dentate gyrus during postnatal development. J Neurosci. 2000;20:8435-42.

199. Liu W, Ye P, O'Kusky JR, D'Ercole AJ. Type 1 insulin-like growth factor receptor signaling is essential for the development of the hippocampal formation and dentate gyrus. J Neurosci Res. 2009;87:2821-32.

200. Huang EJ, Reichardt LF. Neurotrophins: roles in neuronal development and function. Annu Rev Neurosci. 2001:24:677-736.

201. Snider WD. Functions of the neurotrophins during nervous system development: what the knockouts are teaching us. Cell. 1994;77:627-38.

202. Lambiase A, Rama P, Bonini S, Caprioglio G, Aloe L. Topical treatment with nerve growth factor for corneal neurotrophic ulcers. N Engl J Med. 1998; 338:1174-80.

203. McAllister AK. Neurotrophins and neuronal differentiation in the central nervous system. Cell Mol Life Sci. 2001;58:1054-60.

204. Frielingsdorf $\mathrm{H}$, Simpson DR, Thal LJ, Pizzo DP. Nerve growth factor promotes survival of new neurons in the adult hippocampus. Neurobiol Dis. 2007;26:47-55

205. Lee J, Duan W, Mattson MP. Evidence that brain-derived neurotrophic factor is required for basal neurogenesis and mediates, in part, the enhancement of neurogenesis by dietary restriction in the hippocampus of adult mice. J Neurochem. 2002;82:1367-75.

206. Nguyen N, Lee SB, Lee YS, Lee KH, Ahn JY. Neuroprotection by NGF and BDNF against neurotoxin-exerted apoptotic death in neural stem cells are mediated through Trk receptors, activating PI3-kinase and MAPK pathways. Neurochem Res. 2009;34:942-51.
207. Lee JS, Jang DJ, Lee N, Ko HG, Kim H, Kim YS, Kim B, Son J, Kim SH, Chung $\mathrm{H}$, et al. Induction of neuronal vascular endothelial growth factor expression by CAMP in the dentate gyrus of the hippocampus is required for antidepressant-like behaviors. J Neurosci. 2009:29:8493-505.

208. Snyder JS, Radik R, Wojtowicz JM, Cameron HA. Anatomical gradients of adult neurogenesis and activity: young neurons in the ventral dentate gyrus are activated by water maze training. Hippocampus. 2009;19:360-70.

209. Yoshimizu T, Chaki S. Increased cell proliferation in the adult mouse hippocampus following chronic administration of group II metabotropic glutamate receptor antagonist, MGS0039. Biochem Biophys Res Commun. 2004;315:493-6.

210. Bunk EC, Konig HG, Prehn JH, Kirby BP. Effect of the N-methyl-D-aspartate NR2B subunit antagonist ifenprodil on precursor cell proliferation in the hippocampus. J Neurosci Res. 2014;92:679-91.

211. Fiske BK, Brunjes PC. NMDA receptor regulation of cell death in the rat olfactory bulb. J Neurobiol. 2001;47:223-32.

212. Castiglione M, Calafiore M, Costa L, Sortino MA, Nicoletti F, Copani A. Group I metabotropic glutamate receptors control proliferation, survival and differentiation of cultured neural progenitor cells isolated from the subventricular zone of adult mice. Neuropharmacology. 2008;55:560-7.

213. Song J, Sun J, Moss J, Wen Z, Sun GJ, Hsu D, Zhong C, Davoudi H, Christian KM, Toni N, et al. Parvalbumin interneurons mediate neuronal circuitryneurogenesis coupling in the adult hippocampus. Nat Neurosci. 2013;16: 1728-30.

214. Giachino C, De Marchis S, Giampietro C, Parlato R, Perroteau I, Schutz G, Fasolo A, Peretto P. CAMP response element-binding protein regulates differentiation and survival of newborn neurons in the olfactory bulb. J Neurosci. 2005:25:10105-18.

215. Jagasia R, Steib K, Englberger E, Herold S, Faus-Kessler T, Saxe M, Gage FH, Song $H$, Lie DC. GABA-CAMP response element-binding protein signaling regulates maturation and survival of newly generated neurons in the adult hippocampus. J Neurosci. 2009:29:7966-77.

216. Benninghoff J, Gritti A, Rizzi M, Lamorte G, Schloesser RJ, Schmitt A, Robel S, Genius J, Moessner R, Riederer P, et al. Serotonin depletion hampers survival and proliferation in neurospheres derived from adult neural stem cells. Neuropsychopharmacology. 2010;35:893-903.

217. Diaz SL, Narboux-Neme N, Trowbridge S, Scotto-Lomassese S, Kleine Borgmann FB, Jessberger S, Giros B, Maroteaux L, Deneris E, Gaspar P. Paradoxical increase in survival of newborn neurons in the dentate gyrus of mice with constitutive depletion of serotonin. Eur J Neurosci. 2013;38:2650-8.

218. Djavadian RL. Serotonin and neurogenesis in the hippocampal dentate gyrus of adult mammals. Acta Neurobiol Exp. 2004;64:189-200.

219. Chiu WH, Carlsson T, Depboylu C, Hoglinger GU, Oertel WH, Ries V. Selegiline normalizes, while I-DOPA sustains the increased number of dopamine neurons in the olfactory bulb in a 6-OHDA mouse model of Parkinson's disease. Neuropharmacology. 2014;79:212-21.

220. Takamura N, Nakagawa S, Masuda T, Boku S, Kato A, Song N, An Y, Kitaich $Y$, Inoue T, Koyama T, Kusumi I. The effect of dopamine on adult hippocampal neurogenesis. Prog Neuro-Psychopharmacol Biol Psychiatry. 2014;50:116-24

221. Campbell NR, Fernandes CC, Halff AW, Berg DK. Endogenous signaling through alpha7-containing nicotinic receptors promotes maturation and integration of adult-born neurons in the hippocampus. J Neurosci. 2010; 30:8734-44.

222. Bruel-Jungerman $E$, Lucassen PJ, Francis F. Cholinergic influences on cortical development and adult neurogenesis. Behav Brain Res. 2011 221:379-88.

223. Cooper-Kuhn CM, Winkler J, Kuhn HG. Decreased neurogenesis after cholinergic forebrain lesion in the adult rat. J Neurosci Res. 2004;77:155-65.

224. Kaneko N, Okano H, Sawamoto K. Role of the cholinergic system in regulating survival of newborn neurons in the adult mouse dentate gyrus and olfactory bulb. Genes Cells. 2006;11:1145-59.

225. Mohapel P, Leanza G, Kokaia M, Lindvall O. Forebrain acetylcholine regulates adult hippocampal neurogenesis and learning. Neurobiol Aging. 2005; 26:939-46.

226. Malaterre J, Ramsay RG, Mantamadiotis T. Wnt-Frizzled signalling and the many paths to neural development and adult brain homeostasis. Front Biosci. 2007:12:492-506.

227. Lie DC, Colamarino SA, Song HJ, Desire L, Mira H, Consiglio A, Lein ES, Jessberger S, Lansford H, Dearie AR, Gage FH. Wnt signalling regulates adult hippocampal neurogenesis. Nature. 2005;437:1370-5. 
228. Machold R, Hayashi S, Rutlin M, Muzumdar MD, Nery S, Corbin JG, GritliLinde A, Dellovade T, Porter JA, Rubin LL, et al. Sonic hedgehog is required for progenitor cell maintenance in telencephalic stem cell niches. Neuron. 2003;39:937-50

229. Kuwabara T, Hsieh J, Muotri A, Yeo G, Warashina M, Lie DC, Moore L, Nakashima K, Asashima M, Gage FH. Wnt-mediated activation of NeuroD1 and retro-elements during adult neurogenesis. Nat Neurosci. 2009;12: 1097-105.

230. Jang MH, Bonaguidi MA, Kitabatake $Y$, Sun J, Song J, Kang E, Jun H, Zhong C, Su Y, Guo JU, et al. Secreted frizzled-related protein 3 regulates activitydependent adult hippocampal neurogenesis. Cell Stem Cell. 2013;12:215-23.

231. Zhou L, Fester L, Haghshenas S, de Vrese X, von Hacht R, Gloger S, Brandt N, Bader M, Vollmer G, Rune GM. Oestradiol-induced synapse formation in the female hippocampus: roles of oestrogen receptor subtypes. J Neuroendocrinol. 2014;26:439-47.

232. Hamson DK, Wainwright SR, Taylor JR, Jones BA, Watson NV, Galea LA. Androgens increase survival of adult-born neurons in the dentate gyrus by an androgen receptor-dependent mechanism in male rats. Endocrinology. 2013;154:3294-304.

233. Banasr M, Hery M, Brezun JM, Daszuta A. Serotonin mediates oestrogen stimulation of cell proliferation in the adult dentate gyrus. Eur J Neurosci. 2001;14:1417-24.

234. Shingo T, Gregg C, Enwere E, Fujikawa H, Hassam R, Geary C, Cross JC, Weiss $\mathrm{S}$. Pregnancy-stimulated neurogenesis in the adult female forebrain mediated by prolactin. Science. 2003;299:117-20.

235. Furuta M, Bridges RS. Gestation-induced cell proliferation in the rat brain. Brain Res Dev Brain Res. 2005;156:61-6.

236. Zhang Z, Yang R, Zhou R, Li L, Sokabe M, Chen L. Progesterone promotes the survival of newborn neurons in the dentate gyrus of adult male mice. Hippocampus. 2010;20:402-12.

237. Marin-Burgin A, Mongiat LA, Pardi MB, Schinder AF. Unique processing during a period of high excitation/inhibition balance in adult-born neurons. Science. 2012;335:1238-42.

238. Mirescu C, Gould E. Stress and adult neurogenesis. Hippocampus. 2006; 16:233-8.

239. Kempermann G, Brandon EP, Gage FH. Environmental stimulation of $129 / \mathrm{SvJ}$ mice causes increased cell proliferation and neurogenesis in the adult dentate gyrus. Curr Biol. 1998:8:939-42.

240. Kempermann G, Chesler EJ, Lu L, Williams RW, Gage FH. Natural variation and genetic covariance in adult hippocampal neurogenesis. Proc Natl Acad Sci U S A. 2006;103:780-5.

241. Wu CW, Chang YT, Yu L, Chen HI, Jen CJ, Wu SY, Lo CP, Kuo YM. Exercise enhances the proliferation of neural stem cells and neurite growth and survival of neuronal progenitor cells in dentate gyrus of middle-aged mice. J Appl Physiol. 2008;105:1585-94

242. Rochefort C, Gheusi G, Vincent JD, Lledo PM. Enriched odor exposure increases the number of newborn neurons in the adult olfactory bulb and improves odor memory. J Neurosci. 2002;22:2679-89.

243. Rochefort C, Lledo PM. Short-term survival of newborn neurons in the adult olfactory bulb after exposure to a complex odor environment. Eur J Neurosci. 2005;22:2863-70.

244. Corotto FS, Henegar JR, Maruniak JA. Odor deprivation leads to reduced neurogenesis and reduced neuronal survival in the olfactory bulb of the adult mouse. Neuroscience. 1994;61:739-44.

245. Alonso M, Viollet C, Gabellec MM, Meas-Yedid V, Olivo-Marin JC, Lledo PM. Olfactory discrimination learning increases the survival of adult-born neurons in the olfactory bulb. J Neurosci. 2006;26:10508-13.

246. Gould E, Tanapat P, McEwen BS, Flugge G, Fuchs E. Proliferation of granule cell precursors in the dentate gyrus of adult monkeys is diminished by stress. Proc Natl Acad Sci U S A. 1998;95:3168-71.

247. Van Bokhoven P, Oomen CA, Hoogendijk WJ, Smit AB, Lucassen PJ, Spijker S. Reduction in hippocampal neurogenesis after social defeat is long-lasting and responsive to late antidepressant treatment. Eur J Neurosci. 2011;33: 1833-40.

248. Lagace DC, Donovan MH, DeCarolis NA, Farnbauch LA, Malhotra S, Berton O, Nestler EJ, Krishnan V, Eisch AJ. Adult hippocampal neurogenesis is functionally important for stress-induced social avoidance. Proc Natl Acad Sci U S A. 2010;107:4436-41.

249. Bruel-Jungerman E, Davis S, Rampon C, Laroche S. Long-term potentiation enhances neurogenesis in the adult dentate gyrus. J Neurosci. 2006; 26:5888-93.
250. Chun SK, Sun W, Park JJ, Jung MW. Enhanced proliferation of progenitor cells following long-term potentiation induction in the rat dentate gyrus. Neurobiol Learn Mem. 2006;86:322-9.

251. Jukkola PI, Rogers JT, Kaspar BK, Weeber EJ, Nishijima I. Secretin deficiency causes impairment in survival of neural progenitor cells in mice. Hum Mol Genet. 2011;20:1000-7.

252. Sairanen M, Lucas G, Ernfors P, Castren M, Castren E. Brain-derived neurotrophic factor and antidepressant drugs have different but coordinated effects on neuronal turnover, proliferation, and survival in the adult dentate gyrus. J Neurosci. 2005;25:1089-94.

253. Cameron HA, Gould E. Adult neurogenesis is regulated by adrenal steroids in the dentate gyrus. Neuroscience. 1994;61:203-9.

254. Kobilo T, Liu QR, Gandhi K, Mughal M, Shaham Y, van Praag H. Running is the neurogenic and neurotrophic stimulus in environmental enrichment. Learn Mem. 2011;18:605-9.

255. Glasper ER, Llorens-Martin MV, Leuner B, Gould E, Trejo JL. Blockade of insulin-like growth factor-I has complex effects on structural plasticity in the hippocampus. Hippocampus. 2010;20:706-12.

256. Yoshihara S, Takahashi H, Tsuboi A. Molecular Mechanisms Regulating the Dendritic Development of Newborn Olfactory Bulb Interneurons in a Sensory Experience-Dependent Manner. Front Neurosci. 2015;9:514.

257. Yon MA, Mauger SL, Pickavance LC. Relationships between dietary macronutrients and adult neurogenesis in the regulation of energy metabolism. Br J Nutr. 2013;109:1573-89.

258. Siervo M, Arnold R, Wells JC, Tagliabue A, Colantuoni A, Albanese E, Brayne C, Stephan BC. Intentional weight loss in overweight and obese individuals and cognitive function: a systematic review and meta-analysis. Obes Rev. 2011;12:968-83.

259. Garza JC, Guo M, Zhang W, Lu XY. Leptin increases adult hippocampal neurogenesis in vivo and in vitro. J Biol Chem. 2008;283:18238-47.

260. Moon M, Kim S, Hwang L, Park S. Ghrelin regulates hippocampal neurogenesis in adult mice. Endocr J. 2009;56:525-31.

261. Zhang W, Hu Y, Lin TR, Fan Y, Mulholland MW. Stimulation of neurogenesis in rat nucleus of the solitary tract by ghrelin. Peptides. 2005;26:2280-8.

262. Stranahan AM, Arumugam TV, Cutler RG, Lee K, Egan JM, Mattson MP. Diabetes impairs hippocampal function through glucocorticoid-mediated effects on new and mature neurons. Nat Neurosci. 2008;11:309-17.

263. Guo J, Yu C, Li H, Liu F, Feng R, Wang H, Meng Y, Li Z, Ju G, Wang J. Impaired neural stem/progenitor cell proliferation in streptozotocin-induced and spontaneous diabetic mice. Neurosci Res. 2010;68:329-36.

264. Olariu A, Cleaver KM, Cameron HA. Decreased neurogenesis in aged rats results from loss of granule cell precursors without lengthening of the cell cycle. J Comp Neurol. 2007;501:659-67.

265. Belluardo N, Mudo G, Bonomo A, Di Liberto V, Frinchi M, Fuxe K. Nicotineinduced fibroblast growth factor-2 restores the age-related decline of precursor cell proliferation in the subventricular zone of rat brain. Brain Res. 2008;1193:12-24.

266. Bouab M, Paliouras GN, Aumont A, Forest-Berard K, Fernandes KJ. Aging of the subventricular zone neural stem cell niche: evidence for quiescenceassociated changes between early and mid-adulthood. Neuroscience. 2011;173:135-49.

267. Luo J, Daniels SB, Lennington JB, Notti RQ, Conover JC. The aging neurogenic subventricular zone. Aging Cell. 2006;5:139-52.

268. Rao MS, Hattiangady B, Shetty AK. The window and mechanisms of major age-related decline in the production of new neurons within the dentate gyrus of the hippocampus. Aging Cell. 2006;5:545-58.

269. Kim HJ, Kim JY, Sun W. Age-dependent changes in the subcallosal zone neurogenesis of mice. Neurochem Int. 2012;61:879-84.

270. Encinas JM, Sierra A. Neural stem cell deforestation as the main force driving the age-related decline in adult hippocampal neurogenesis. Behav Brain Res. 2012;227:433-9.

271. Meletis K, Wirta V, Hede SM, Nister M, Lundeberg J, Frisen J. p53 suppresses the self-renewal of adult neural stem cells. Development. 2006;133:363-9.

272. Furutachi S, Matsumoto A, Nakayama Kl, Gotoh Y. p57 controls adult neural stem cell quiescence and modulates the pace of lifelong neurogenesis. EMBO J. 2013:32:970-81. 